\title{
Genomic rearrangements of mobile genetic elements associated with carbapenem resistance of Acinetobacter baumannii
}

Saranya Vijayakumar ${ }^{1}$, Jobin Jacob John ${ }^{1}$, Karthick Vasudevan ${ }^{2}$, Purva Mathur ${ }^{3}$, Pallab Ray ${ }^{4}$, Ayyanraj Neeravi ${ }^{1}$, Asthawarthani Baskaran ${ }^{1}$, Agilandeeswari Kirubananthan ${ }^{1}$, Shalini Anandan $^{1}$, Indranil Biswas ${ }^{5}$, Kamini Walia ${ }^{6}$, Balaji Veeraraghavan ${ }^{1}$

${ }^{1}$ Department of Clinical Microbiology, Christian Medical College, Vellore

${ }^{2}$ Reva University, Bangalore

${ }^{3}$ AIIMS Jai Prakash Narayan Apex Trauma Center, New Delhi

${ }^{4}$ Post Graduate Institute of Medical Education \& Research, Chandigarh

${ }^{5}$ Kansas University of Medical Center, Kansas City, United States

${ }^{6}$ Indian Council of Medical Research, New Delhi

Running title: Genomic rearrangements of mobile genetic elements in A. baumannii

Keywords: CRAB, OXA-23, IC2, Tn2006, AbaR4-like, AbGRI-like

\section{Corresponding author:}

Dr. Balaji Veeraraghavan

Professor

Department of Clinical Microbiology

Christian Medical College

Vellore -632004

Email: vbalaji@cmcvellore.ac.in 


\begin{abstract}
:
With the excessive genome plasticity, Acinetobacter baumannii has the capability to acquire and disseminate antimicrobial resistance genes that are often associated with mobile genetic elements (MGE). Analyzing the genetic environment of resistance genes often provides valuable information on the origin, emergence, evolution and spread of resistance. Thus, we characterized the genomic features of some clinical isolates of carbapenem-resistant $A$. baumannii to understand the role of diverse MGE and their genetic context that are responsible for the dissemination of carbapenem resistance genes. For this, a total of 17 clinical isolates of A. baumannii obtained from multiple hospitals in India between the years 2018 and 2019 were analysed. Antimicrobial resistance determinants, genetic context of resistance genes and molecular epidemiology were studied using whole genome sequencing. A high prevalence of $b l a_{\mathrm{OXA}-23}$ was observed followed by the presence of dual carbapenemase, $b l a_{\mathrm{OXA}-23}$ and $b l a_{\mathrm{NDM}}$. Three novel Oxford sequence types were identified. Majority of the isolates belonged to dominant clone, IC2 followed by less prevalent clones such as IC7 and IC8. Complex diverse AbaR4 like and AbGRI-like islands belonging to IC2 lineage were identified. To the best of our knowledge, this is the first study that provides a comprehensive profiling of resistance islands along with the MGE, acquired antimicrobial resistance genes and the distribution of clonal lineages of carbapenem resistant A. baumannii from India.
\end{abstract}




\section{Introduction:}

Acinetobacter baumannii is a member of the ESKAPE group of pathogens and is considered to be one of the major global causes of hospital-acquired infections (HAI) (Elhosseiny et al 2018). A. baumannii is responsible for causing a wide range of infections with pneumonia being the most commonly observed among critically ill patients (Dexter et al 2015). This pathogen has a propensity to rapidly acquire antibiotic resistance genes and develop resistance to multiple classes of antimicrobials (Lee et al., 2017). Carbapenems are one of the commonly used choices of antibiotic for Acinetobacter infections. Carbapenem resistance in Asia-Pacific region ranges between 70 to $85 \%$ (O'Donnell et al., 2021). A recent study from SENTRY surveillance reported increased carbapenem resistance rate ranging from $55 \%$ to 90\% in India (Gales 2019). Both CDC and WHO categorized carbapenem resistant $A$. baumannii (CRAB) under 'Urgent Threat' and as priority 1: critical pathogen, respectively. Recently, the WHO Country Office for India developed Indian Priority Pathogen List (IPPL) and categorized carbapenem resistant, colistin resistant A. baumannii under 'Critical Priority' (https://dbtindia.gov.in).

With excessive genome plasticity, A. baumannii has the capability to acquire and disseminate antimicrobial resistance (AMR) genes that are often associated with various mobile genetic elements (MGEs) (Roca et al 2012). Carbapenem resistance in A. baumannii is mainly due to the presence of genes encoding class B metallo- $\beta$-lactamase, $b l a_{\mathrm{NDM}}$-like and class D oxacillinases, $b l a_{\text {OXA-23-like, }} b l a_{\text {OXA-51-like }}$ and $b l a_{\text {OXA-58-like }}$ enzymes (Vijayakumar et al 2016). Worldwide, bla $_{\mathrm{OXA}-23}$ gene is the most predominant and is carried on a range of MGEs including insertion sequences (ISs), transposons, integrons, plasmids and resistance islands (RIs) (Pagano et al, 2016). In A. baumannii, all these elements lead to a further contribution to the broader mobilization of other AMR genes (Pagano et al 2016; Patridge et al 2018). 
The association of IS elements with $b l a_{\mathrm{OXA}-51-l i k e, ~} b l a_{\mathrm{OXA}-23-\text { like }}, b l a_{\mathrm{NDM}-\text { like }}$ and $b l a_{\mathrm{OXA}-58 \text {-like }}$

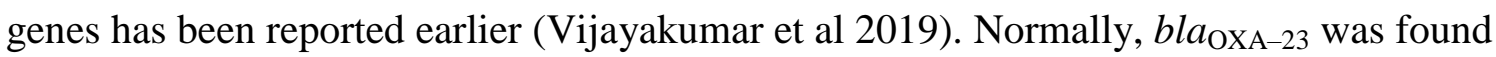
associated with transposons such as Tn2006, Tn2008 and Tn2009, whilst bla $a_{\mathrm{NDM}}$ has been mobilized by the Tn125-like composite transposon (Pagano et al 2016). Reports from recent studies also indicate the role of conjugative plasmids as vehicles for disseminating resistance determinants in A. baumannii (Salto et al 2018). Additionally and most importantly, the emergence of A. baumannii resistance (AbaR) islands carrying clusters of horizontally transferred genes is considered a major contributor to the multidrug-resistant (MDR) phenotype of A. baumannii (Cameranesi et al., 2020). AbaR islands are diverse and carry distinct transposons like Tn6019, Tn6022 and Tn6172 that are known to be involved in resistance to multiple antibiotics and heavy metals (Pagano et al 2016). Earlier reports assessing the diversity of AbaR islands in A. baumannii suggest different backbones in different epidemic clones (Bi et al., 2019).The AbaR3-type elements are confined to International Clone 1 (IC1) and comprise a Tn6019 backbone and are consistently linked with Tn6018 or its elements with multiple antimicrobial resistance regions (MARRs) (Dexi et. al. 2020). Similarly, Tn6022 is the predominant backbone mostly found in International

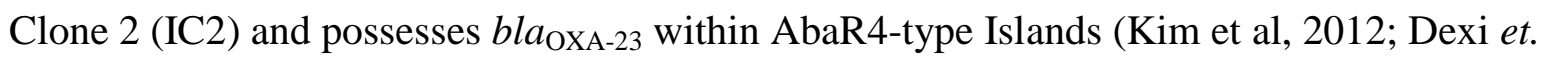
al. 2019; Dexi et. al. 2020). However, recent studies have shown that AbaRs that lack bla OXA23-like was replaced by AbaR4, AbaR25 or AbGRI that carries bla $a_{\mathrm{OXA}-23}$ in a Tn2006 transposon (Hamidian, 2011). Table 1 outlines the genomic and epidemiological features of different clones of carbapenem resistant A. baumannii.

Though the endemic burden of CRAB is a major public health problem in Indian hospital settings, lack of genomic information makes it difficult to track its persistence (MancillaRojano et al., 2019). Studying the genetic environment of resistance genes often provides 
valuable information on the origin, emergence, evolution and spread of resistance in the bacterial populations (Hamidian et al 2019).

We aimed to characterize the prevalent genomic features of clinical isolates of carbapenemresistant A. baumannii that are circulating in India. We found that the backbone of MGE and their association with antimicrobial resistance genes are similar to that of the global context. We also compared the structural configuration of RIs with the complete genetic information and observed structural variations within the genetic environment of resistance genes.

\section{Materials and methods:}

\section{Bacterial isolates}

A total of 17 clinical isolates of $A$. baumannii were used. Of the 17 isolates included in this study, 13 were from CMC, Vellore, three from AIIMS-trauma center, Delhi and one from PGIMER, Chandigarh. Among the isolates, 10 isolates were from blood $(B ; n=10)$, six from endo-tracheal aspirate (ETA; $n=6)$ and one from pus $(P ; n=1)$. Phenotypic characterization of all the isolates as A. baumannii calcoaceticus complex (Acb) complex was determined using standard biochemical tests. Confirmation of $A c b$ complex at the species level was done by Vitek-MS (Database v2.0, bioMerieux, France) as described earlier and by the identification of chromosomally encoded bla $a_{\text {OXA-51 like }}$ gene by PCR (Turton et al., 2006).

\section{Antimicrobial susceptibility testing (AST)}

All the isolates were characterized for susceptibility to cephalosporins, $\beta$-lactam/ $\beta$-lactamase inhibitors, fluoroquinolones, aminoglycosides, tetracycline, minocycline and tigecycline by Kirby Bauer's disc diffusion (DD) method. For colistin, broth-microdilution (BMD) was performed. Isolates identified as carbapenem-resistant by DD were further subjected to BMD to determine the minimum inhibitory concentration (MIC) for imipenem and meropenem. The susceptibility was interpreted as per the criteria defined by CLSI guidelines (CLSI 2018, CLSI 2019). Escherichia coli (ATCC 25922) and Pseudomonas aeruginosa (ATCC 27853) 
were included in every batch for quality control (QC). For colistin susceptibility testing, in addition to QC strains, a mcr-1 positive E. coli isolate and two Klebsiella pneumoniae strains (BA38416 and BA25425) were also included as QC.

\section{Whole genome sequencing (WGS) and assembly}

The isolates were recovered overnight on blood agar and genomic DNA was extracted from pure cultures using QIAamp DNA mini kit (Qiagen, Germany) following the manufacturers' instruction. DNA was quantified using NanoDrop spectrophotometry (Thermo Fisher Scientific, USA) and Qubit 3.0 fluorometry (Life Technologies, USA) and stored at $-20^{\circ} \mathrm{C}$ until further characterization.

Short read sequencing of the 17 isolates were carried out with IonTorrent $\mathrm{PGM}^{\mathrm{TM}}$ platform using 400-bp chemistry (Life Technologies, USA) or 150-bp paired-end sequencing using HiSeq 2500 platform (Illumina, USA). PHRED quality score was checked on the sequences and the reads with a score below 20 were discarded. Adapters were trimmed using cutadapt v1.8.1 (https://github.com/marcelm/cutadapt) and assessed with FastQC v0.11.4 (http://www.bioinformatics.babraham.ac.uk/projects/fastqc).

All the isolates were further subjected to Oxford Nanopore MinION sequencing (Oxford Nanopore Technologies, UK) to obtain long-read sequences. For this, long read DNA library was prepared as per the manufacturer's protocol using the SQK-LSK108 ligation sequencing kit (v.R9) along with ONT EXP-NBD103 Native Barcode Expansion kit (Oxford Nanopore Technologies, UK). The library was loaded onto the FLO-MIN106 R9 flow cell; run for 48 hours using the standard MinKNOW software. The Fast5 files generated from MinION sequencing were subjected to base calling using Guppy (https://github.com/gnetsanet/ONTGUPPY).

Complete circular genomes for the 17 isolates were obtained using de novo hybrid assembly of Illumina and Oxford nanopore sequences as described earlier (Vasudevan et al., 2019). 
The long reads were error-corrected using standalone Canu tool (v.1.7) and filtered using Filtlong v 0.2.0 (https://github.com/rrwick/Filtlong) with parameters set at min_length 1000 $90 \%$. Short reads generated using ion torrent was error-corrected using Ionhammer (Ershov et al., 2018) available in SPAdes and the default fasta output was converted to fastq with custom scripts. Additionally, genomes were assembled using the Unicycler hybrid assembly pipeline (v 0.4.6) with the default settings (Wick et al., 2017). The obtained genome sequence were polished using high quality Illumina/Ion torrent reads to reduce the base level errors with multiple rounds of Pilon (v.1.22) (Walker et al, 2014). The quality of assembly was assessed for completeness, correctness, and contiguity using CheckM v1.0.5 (Parks et al., 2015).

\section{Genome analysis}

The genome sequences were submitted to NCBI and annotated using Prokaryotic Genome Annotation Pipeline (PGAP v.4.1) (www.ncbi.nlm.nih.gov/genome/annotation_prok/). Accession numbers obtained from NCBI are listed in Tables 2 and 3. Further downstream analysis on the 17 complete genome sequences was performed using tools available at the Center for Genomic Epidemiology (CGE) (https://cge.cbs.dtu.dk/services/). Antimicrobial resistance genes were identified from the genome sequences using the BLASTn-based ABRicate (v. 0.8.10) program (https://github.com/tseemann/abricate) to query the ResFinder database (https://cge.cbs.dtu.dk/services/ResFinder/). The Capsular Polysaccharide loci (KL) and Outer Core Lipooligosaccharide loci (OCL) types were identified using the Kaptive database (https://kaptive-web.erc.monash.edu/).

The presence of insertion sequences was identified using ISFinder (https://wwwis.biotoul.fr/blast.php). Using BLAST analysis, the plasmid repAci types from the complete genomes were identified and characterized (Table 2). BLAST- similarity search was performed on individual genomes to identify the comM region that flank AbaR type islands. 
Based on the known AbaR sequences collected from published literature, the precise boundary of AbaRs and the respective backbone were curated manually. The sequence types were identified with MLST Finder 2.0 using both Oxford and Pasteur schemes (https://cge.cbs.dtu.dk/services/MLST/).

\section{Phylogenetic analysis}

The assembled genome sequences were mapped to the reference genome ATCC 17978 (CP012004) using the BWA MEM (https://github.com/lh3/bwa) algorithm and the variants were filtered with FreeBayes available in Snippy (Seemann, 2015). The core SNP genome alignment of all the genomes was generated with snippy-core. The recombination regions within the core genome alignment were further filtered and removed using the Gubbins (v. 2.4.1) algorithm (Croucher et al., 2015). The maximum likelihood (ML) phylogeny was constructed using FastTree v.2.1.8 (Price et al., 2009) using GTR model with 100 bootstrap replicates. The phylogenetic tree was rooted with the reference genome and labeled using the Interactive Tree of Life software (iTOL v.3) (Letunic and Bork, 2021).

\section{Results}

\section{Varied resistance of $A$. baumannii strains with bla ${ }_{O X A-51}$ and bla $a_{O X A-23}$ variants}

All the 17 isolates were phenotypically identified as $A c b$-complex and further re-confirmed as A. baumannii using Vitek-MS (Data not shown). Among the 17 isolates, one was pansusceptible (PSAB), one was multi-drug resistant (MDRAB) but susceptible to carbapenem $(\mathrm{CSAB}), 12$ isolates were carbapenem resistant $(\mathrm{CRAB})$ and remaining three isolates were pan-drug resistant (PDRAB). Table 2 outlines the presence of resistance genes among the 17 isolates against different class of antimicrobials. All the study isolates carried the intrinsic $b l a_{\text {OXA-51 }}$ like gene. WGS identified seven different variants of bla $a_{\text {OXA-51 }}$ (bla $a_{\text {OXA-66, }}, b_{\text {OXA-68, }}$

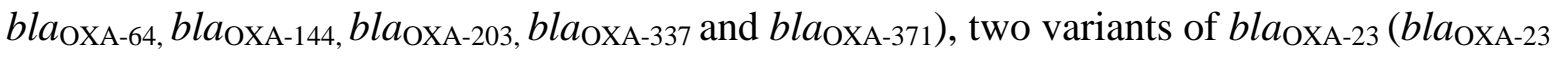


and bla $\left._{\mathrm{OXA}-169}\right)$ and single variant of $b l a_{\mathrm{NDM}}$ like gene ((bla $\left.a_{\mathrm{NDM}-1}\right)$. Among the 17 study isolates, ten carried $b l a_{\mathrm{OXA}-23}$ like alone, one isolate carried $b l a_{\mathrm{NDM}-1}$ alone and four isolates co-harbored $b l a_{\mathrm{OXA}-23}$ like and $b l a_{\mathrm{NDM}-1}$. No carbapenemase genes were identified in two isolates. More than one copy of bla $a_{\mathrm{OXA}-23}$ was observed in thirteen isolates (Table 2). As expected \& surprisingly, On the other hand, none of our isolates carried bla ${ }_{\mathrm{OXA}-24}$, and $b l a_{\text {OXA-58 }}$ like genes.

\section{Novel sequence types and associated carbapenemases among diverse clones of CRAB}

The A. baumannii isolates in this study belonged to four ICs (IC1/CC1, IC2/CC2, IC7/CC25 and IC8/CC10) (Table 2). Three novel Oxford STs; ST2439, ST2440 and ST2441 were assigned to four isolates. Nine isolates belonged to the predominant IC2 clone and represented by six diverse Oxford MLST sequence types (ST ${ }^{\mathrm{Oxf}}$ ) (ST195, ST208, ST218, ST349, ST451 and ST848) or a single Pasteur MLST ST2 ${ }^{\text {Pas }}$. IC8 was the second commonest clone represented by three isolates and corresponded to STs: ST447 ${ }^{\text {Oxf }} / \mathrm{ST} 10^{\text {Pas }}$, ST2392 Oxf $/$ ST586 ${ }^{\text {Pas }}$ and ST2441 Oxf $/$ ST575 ${ }^{\text {Pas }}$. Similarly, two isolates belonged to IC7 and was represented by ST1388 ${ }^{\mathrm{Oxf}} / \mathrm{ST} 25^{\mathrm{Pas}}$ and ST691 ${ }^{\mathrm{Oxf}} / \mathrm{ST} 25^{\mathrm{Pas}}$ and one isolate represented IC1 that was corresponded by ST231 ${ }^{\mathrm{Oxf}} / \mathrm{ST} 1^{\text {Pas }}$. The pan-susceptible isolate represented as a singleton and belonged to ST2439 ${ }^{\text {Oxf }} / \mathrm{ST} 285^{\text {Pas }}$ whilst one pan-resistant isolate belonged to CC862 and represented by ST $2440^{\text {Oxf }} / \mathrm{ST} 622^{\text {Pas }}$. We found that $b l a_{\text {OXA-23 was carried by majority of the }}$ study isolates regardless of the ICs. Isolates belonging to IC2, predominantly carried either $b l a_{\mathrm{OXA}-23}$ alone (7/9) or co-produced bla $_{\mathrm{OXA}-23}$ and $b l a_{\mathrm{NDM}-1}(2 / 9)$. Among the isolates belonging to IC8, two were bla $a_{\text {OXA-23 }}$ producers, while one isolate was found to be a noncarbapenemase producer. The two IC7 isolates identified in this study harbored either bla $a_{\text {OXA- }}$ 23 alone or both $b l a_{\mathrm{OXA}-23}$ and $b l a_{\mathrm{NDM}-1}$. bla ${ }_{O X A-23}$ was carried by diverse genetic configurations among Indian CRAB isolates 
Majority of the isolates $(n=14 / 17)$ carried $b a_{\mathrm{OXA}-23}$ in Tn2006, an ISAbal-bounded composite transposon frequently observed in A. baumannii. Among the 14 isolates that carried Tn2006 transposon, 12 were located in chromosome whilst two isolates possess both plasmid-borne and chromosome-borne transposon. (Figure 1A). Figure 1B depicts the common backbone of bla $a_{\text {OXA-51 }}$ along with modified backbone identified in this study. Interestingly, in AB28 which carries variant of bla $_{\text {OXA-51 }}\left(b l a_{\text {OXA-371 }}\right)$, insertion of ISAba16, TnpB, and IS66 transposase was observed without upstream presence or insertional inactivation (Figure 1B).

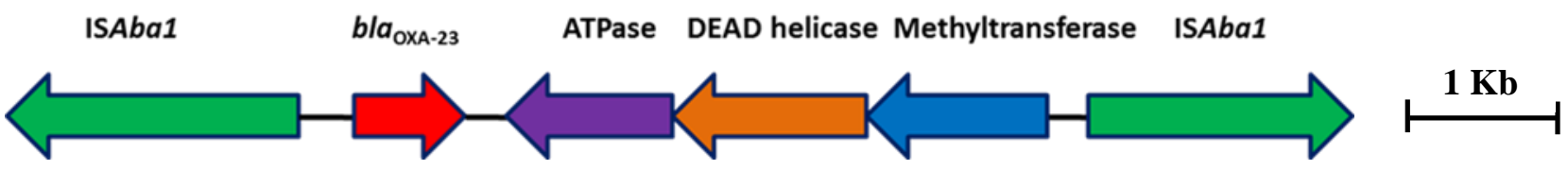

Figure 1A: Genetic arrangement of bla $a_{\text {OXA-23 }}$ identified in this study. The $b l a_{\text {OXA-23 }}$ gene was flanked by two copies of insertion sequence, ISAbal in opposite orientations forming a composite transposon, $\operatorname{Tn} 2006$
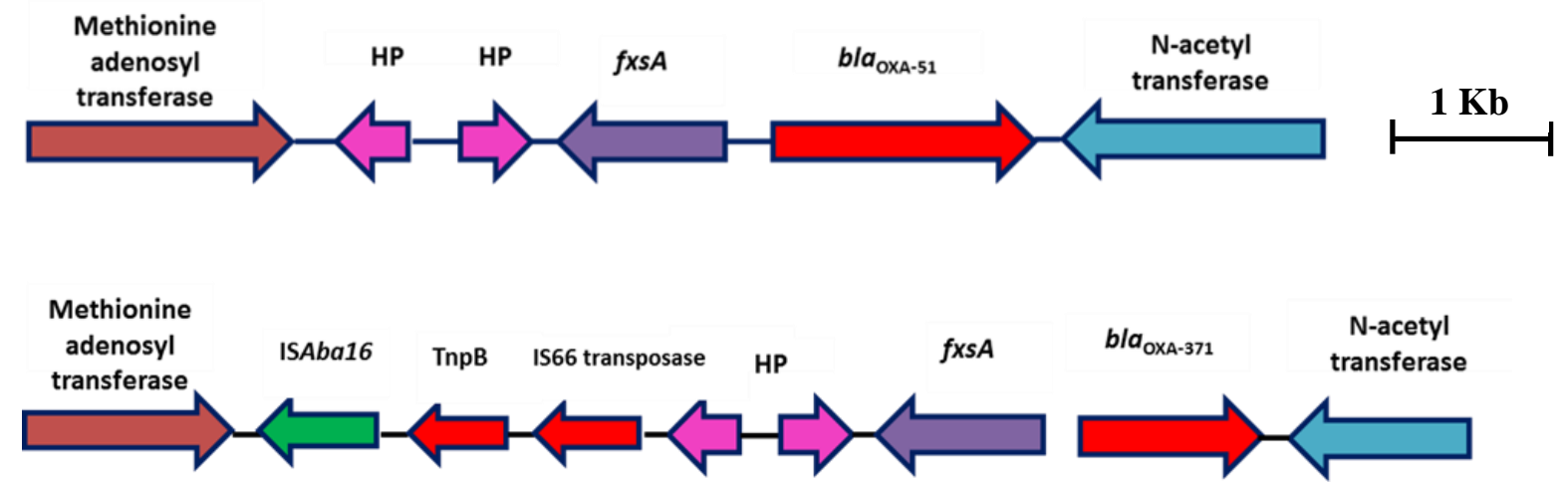

Figure 1B: Genetic backbone of $b l a_{\mathrm{OXA}-51}$. Two types of genetic structures were identified in this study. Sixteen isolates were identified with typical backbone whereas one isolate with $b l a_{\text {OXA-371 }}$ was identified with insertion sequence, ISAba16, TnpB and IS66 family transposase.

Five isolates carried $b l a_{\mathrm{NDM}-1}$ gene on the chromosome. Two different structural variations were noticed in the genetic context of chromosomally inserted $b l_{\mathrm{NDM}-1}$ gene (Figure 2). Four genomes with chromosomally located bla $a_{\mathrm{NDM}-1}(\mathrm{AB} 03, \mathrm{AB} 06, \mathrm{AB} 16$ \& AB28) were associated with the most commonly reported transposon Tn125 (Figure 2A). 
Truncated form of $\operatorname{Tn} 125$ (Tn125-like) was identified in one genome (AB13) where the genome harbors a single copy of ISAba125 and an incomplete transposase at the left-hand and right-hand extremity of $\operatorname{Tn} 125$ respectively (Figure 2B).

2A.

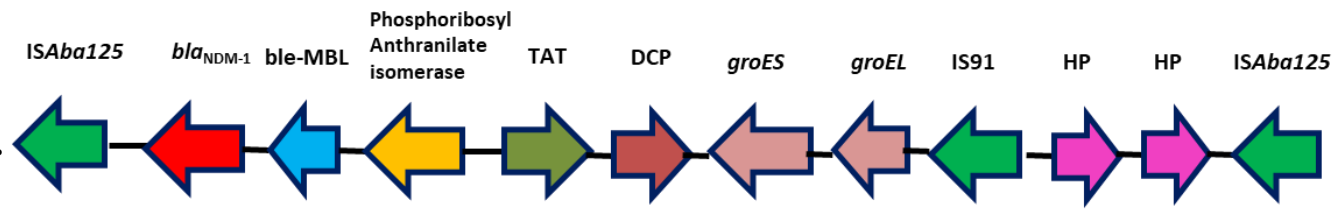

2B.

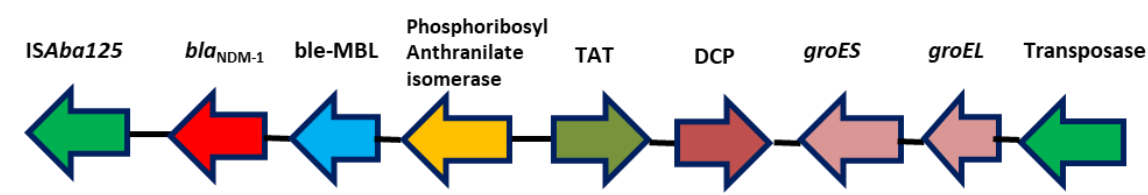

Figure 2: Representative genomes showing the genetic environment of the $b l a_{\mathrm{NDM}-1}$ gene characterized in the present study. 2A. Tn125 - bla $a_{\mathrm{NDM}-1}$ with two copies of ISAba125. 2B.Tn125 like - bla $\mathrm{NDM}_{-1}$ with one copy of ISAbal25 and a truncated transposase

\section{Co-occcurence of bla ${ }_{O X A-23}$ in the chromosome and plasmid}

While the dissemination of CRAB in India is mostly chromosomal mediated, the carbapenemase encoding gene located on a transposon was often mobilized by various plasmids. Table 3 outlines the general features of plasmids including replicon type, AMR gene profile, insertion elements and virulence genes that are present among the 17 isolates of

CRAB. We found that five genomes contained at least one plasmid and 12 genomes contained between two to six plasmids that are ranging in size from $1.8 \mathrm{~kb}$ to $226.4 \mathrm{~kb}$ (Table 3). The bla $a_{\text {OXA-23 }}$ gene was present on the plasmids in two genomes. The plasmid, p1AB28 belongs to IC1 and carried blaxA-23 on repAci6 family plasmid along with several plasmid transfer (tra) genes while the plasmid, p1AB15 carried bla $a_{\mathrm{OXA}-23}$ on an incomplete RepB family plasmid, belonging to IC7. In the plasmid p1AB20, repAci6 was found to carry aphA6 gene within TnaphA6 that was bounded by two copies of ISAba125 in direct orientation and belonged to IC2 clonal type. 
When we analyzed and compared the p1AB28 plasmid sequence with the reference plasmid, pA85-3, we found the presence of a complete $b l a_{\text {OXA-23 }}$ gene with one complete and an incomplete copy of ISAbal locus. However, some transposon related genes such as uspA and sulP were intact. Insertion of IS66 family transposase with its accessory protein, $\operatorname{tn} p B$ was also encoded within p1AB28 plasmid sequence but absent in pA85-3 reference plasmid. The plasmid, p1AB28 also carried putative tra genes that are required for mating pair formation and $\operatorname{tr} w C$ and $\operatorname{tr} w B$ genes that are needed for plasmid mobilization (Figure 3).

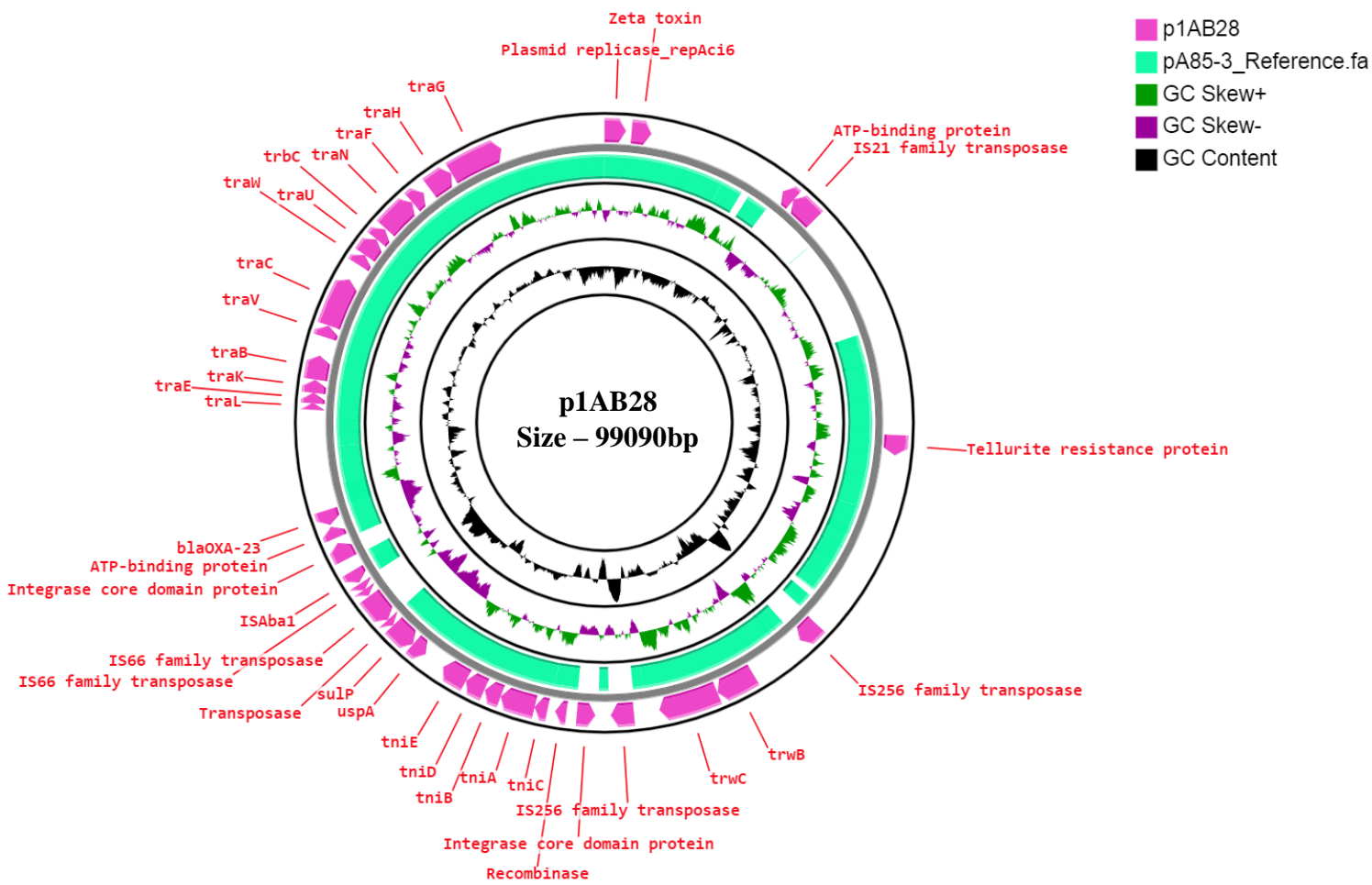

Figure 3: Circular representation of repAci6 plasmid (Pink arrow), p1AB28 of A. baumannii displayed using CG view server with the reference plasmid pA85-3 (Accession number KJ493819) (Green colored region). The two inner circles represent GC content and GC skew. Pink colored arrow represents the presence of OXA-23 gene along with plasmid replication gene, repAci6, tra genes and plasmid mobilization genes in p1AB28.

\section{Predominance of AbaR4-like and AbGRI-like resistance islands among Indian CRAB}

\section{isolates}

AbaR island commonly disrupt the chromosomal comM gene, which is an insertion hotspot

(Bi et al., 2020). Analysis of the $17 \mathrm{CRAB}$ genomes revealed the presence of resistance 
islands with a range of AMR genes along with its associated transposons and insertion elements in 15 genomes while absent in two genomes. Based on the genetic configurations, six different types were identified. One genome encoded Tn6022-derived elements in which insertion of IS256 family transposase, ISAba42 between tniE and orf observed (Tn6022 (tniE-orf)::ISAba42) (AB28) (Figure 4A). We observed that five genomes carried the complete AbaR4 that were all mapped to Tn6022 backbone together with Tn2006 linked

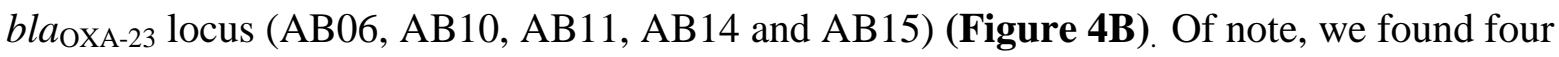
genomes to carry AbaR4-derived elements which include an AbaR4 locus with an additional mobilization gene, mobL (AB03, AB16, AB19 and AB26) (Figure 4B).

In five genomes (AB02, AB13, AB18, AB20 and AB27), AbGRI-type elements were identified that carried complex diverse structures. As depicted in the Figure 5C, complex structural variations were observed in these three genomes. In AB27, two copies of ISAbal were observed. One copy of ISAbal was inserted at tniE of the Tn6022 backbone whereas second copy inserted at tniA of Tn6172. Two copies of Tn2006 were seen; of which one was present in Tn6022 at orf4 while another was present adjacent to orfBA of Tn6172. Insertion of sul2, rcr2 and hypothetical protein at the left inverted repeat of Tn6172 element. In AB18 and AB20, a single copy of ISAbal element, sul2, rcr2 and hypothetical protein were inserted at tniCA element of Tn6172 backbone. Two copies of Tn2006 were observed in both the genomes but differ at insertion site. In AB18, one copy of Tn2006 was inserted at orf4 while second copy in between orfBA and tetracycline resistance transcriptional repressor gene, tetR(B). In AB20, one copy of Tn2006 was observed in between Tn6022 element and plasmid linker whereas another Tn2006 was inserted near to orfBA. Additionally, insertion of arsenic resistance encoding gene, ars $R$ and mobilization gene, $m o b L$ was present in $\operatorname{Tn} 6172$ element of all three genomes (Figure 4C). 
Interestingly, the remaining two genomes (AB02, AB13) carried novel Tn6022-derived, plasmid linker and Tn6172-derived elements. Insertion of a single copy of Tn2006 and $\triangle$ ISCR2- $\triangle$ Tn10-MARR like region in Tn6172 as described earlier by Dexi Bi and colleagues was observed in both the genomes (Bi et al., 2020). However, one minor difference identified between both genomes where one carried blaPER-1 within class 1 integron of Tn6172-derived element whilst another was found to carry class 1 integron and devoid of blaPER-1 (Figure 4D \& 4E).

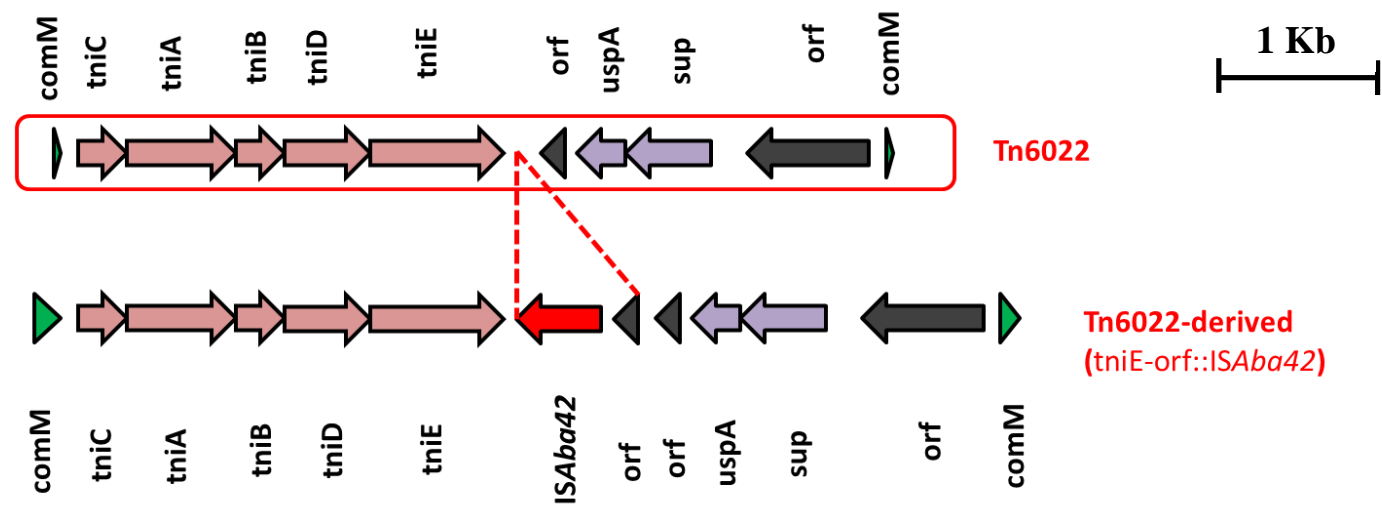

Figure 4A: Structures of Tn6022 and Tn6022-like element. The typical Tn6022

backbone is shown at the top of the figure. Tn6022-derived element observed in this study is displayed at the bottom of the figure and showed the insertion of ISAba42 (red arrow) with an additional orf. Appropriate names of the elements found within the genetic configurations are given. Dotted lines in red are used to depict insertion of genetic elements.
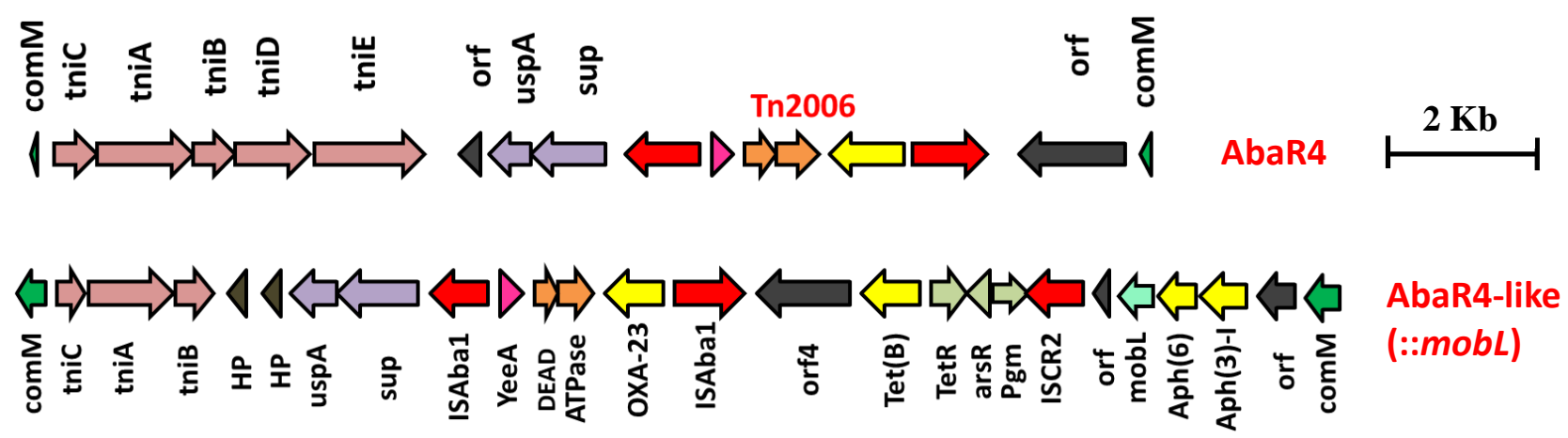
Figure 4B: Structures of AbaR4 and AbaR4-like islands identified in this study. The top figure depicts the typical AbaR4 type island while the bottom figure indicates AbaR4like island due to the presence of additional mobL (light green arrow) and arsenic resistance gene, ars $R$ (light grey arrow). The yellow arrow indicates antimicrobial resistance genes and red arrow depicts insertion elements. 

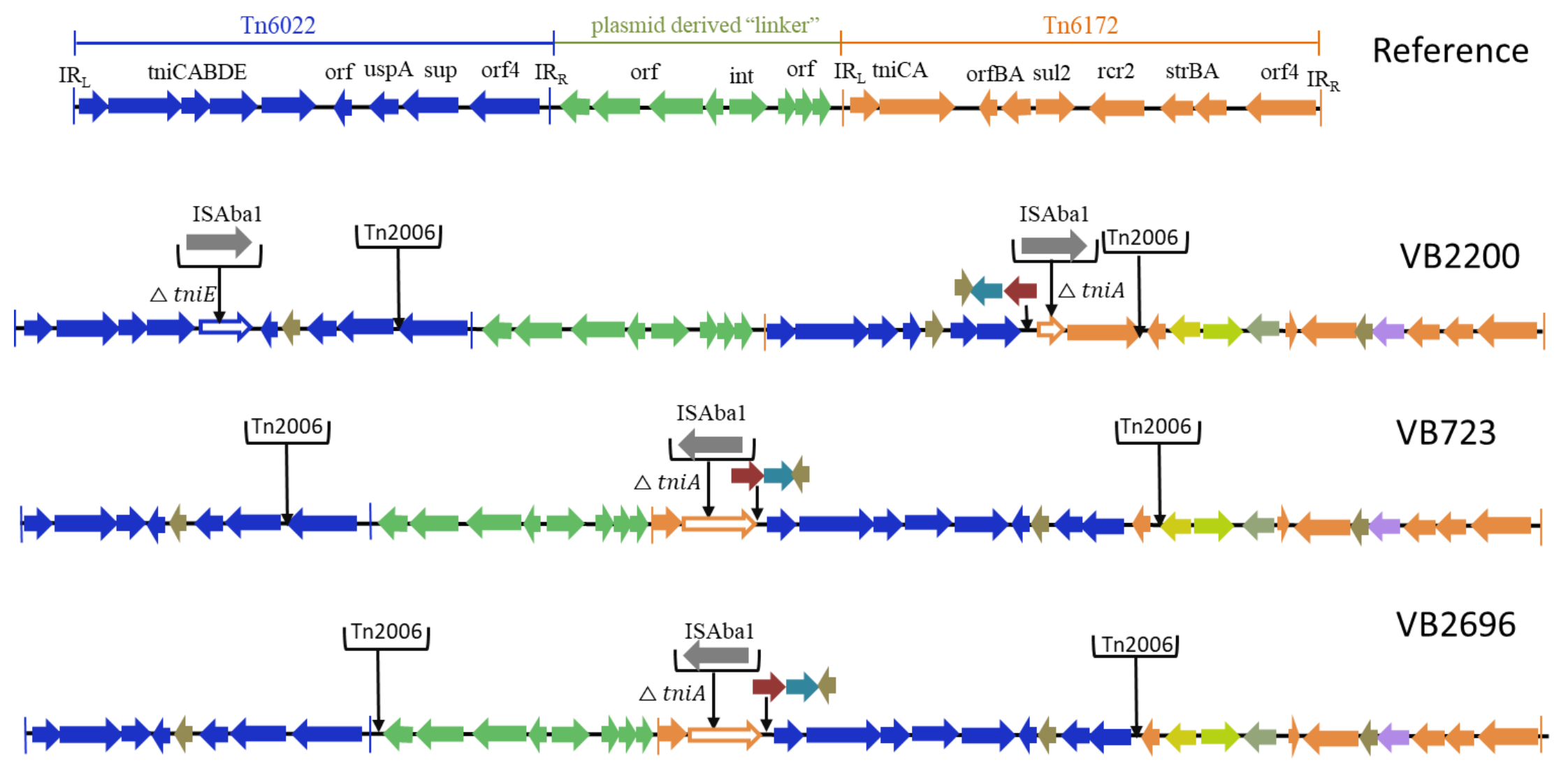

Figure 4C: Structures of AbGRI-type resistance islands identified in this study. The typical AbGRI1 structure with an intact "Tn6022linker-Tn6172" backbone is shown as reference. The Tn6022 or Tn6022-derived part is shown in blue, the Tn6172 part or its partial segments are shown in orange, while the linker region is shown in green. The black arrows shown in downward direction indicates insertion of IS element or transposon or additional genes. 


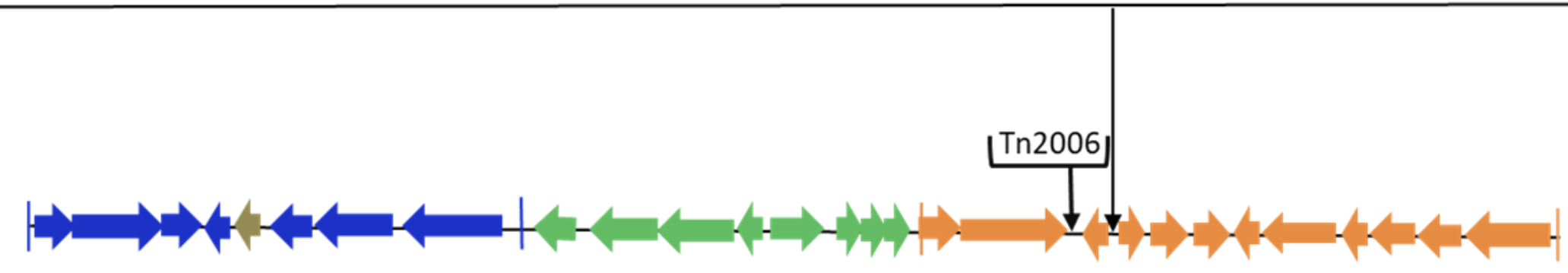

Figure 4D: Genetic backbone of AB13 carrying AbGRI-type resistance island identified in this study. The Tn6022 or Tn6022-derived part is shown in blue, the Tn6172 part or its partial segments are shown in orange, while the linker region is shown in green. The black arrows shown in downward direction indicates insertion of IS element or transposon or additional genes. Pale yellow arrow indicates AMR genes, light green arrow represents tetracycline repressor gene, grey arrow represents insertion elements and brown arrow indicates hypothetical protein.

tet(B) tetR arsR pgm IS91 $\quad$ res $\quad \begin{aligned} & \text { IS91 } \\ & \text { like }\end{aligned}$

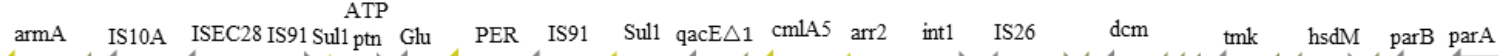
$\begin{array}{lll} & \end{array}$

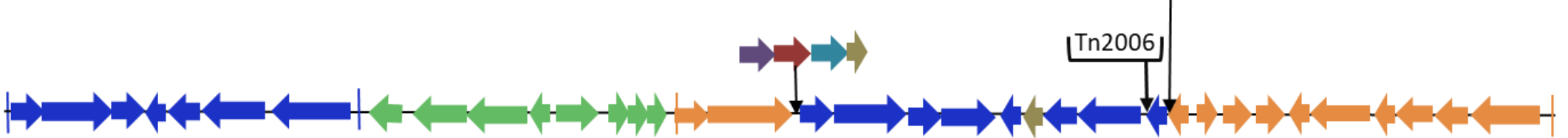


Figure 4E: Genetic backbone of AB02 carrying AbGRI-type resistance island identified in this study. The Tn6022 or Tn6022-derived part is shown in blue, the Tn6172 part or its partial segments are shown in orange, while the linker region is shown in green. The black arrows shown in downward direction indicates insertion of IS element or transposon or additional genes. Pale yellow arrow indicates AMR genes, light green arrow represents tetracycline repressor gene, grey arrow represents insertion elements and brown arrow indicates hypothetical protein. 


\section{AbaR4-like and AbGRI-like islands were confined only among IC2 isolates:}

Analysis of core genomes of CRAB revealed the presence of multiple antimicrobial resistance genes among IC2 isolates. Clone specific OCL types such as OCL1 to IC2, OCL5 to IC7 and OCL2 to IC8 were observed. Diverse KL types were identified among the study isolates and the tree showed the presence of ST specific KL types within a specific clonal lineage. AbaR4 type RI was present among the IC1, IC7 and IC8 isolates whilst AbaR4-like and AbGRI-like resistance Islands were observed only among the IC2 isolates (Figure 5). 


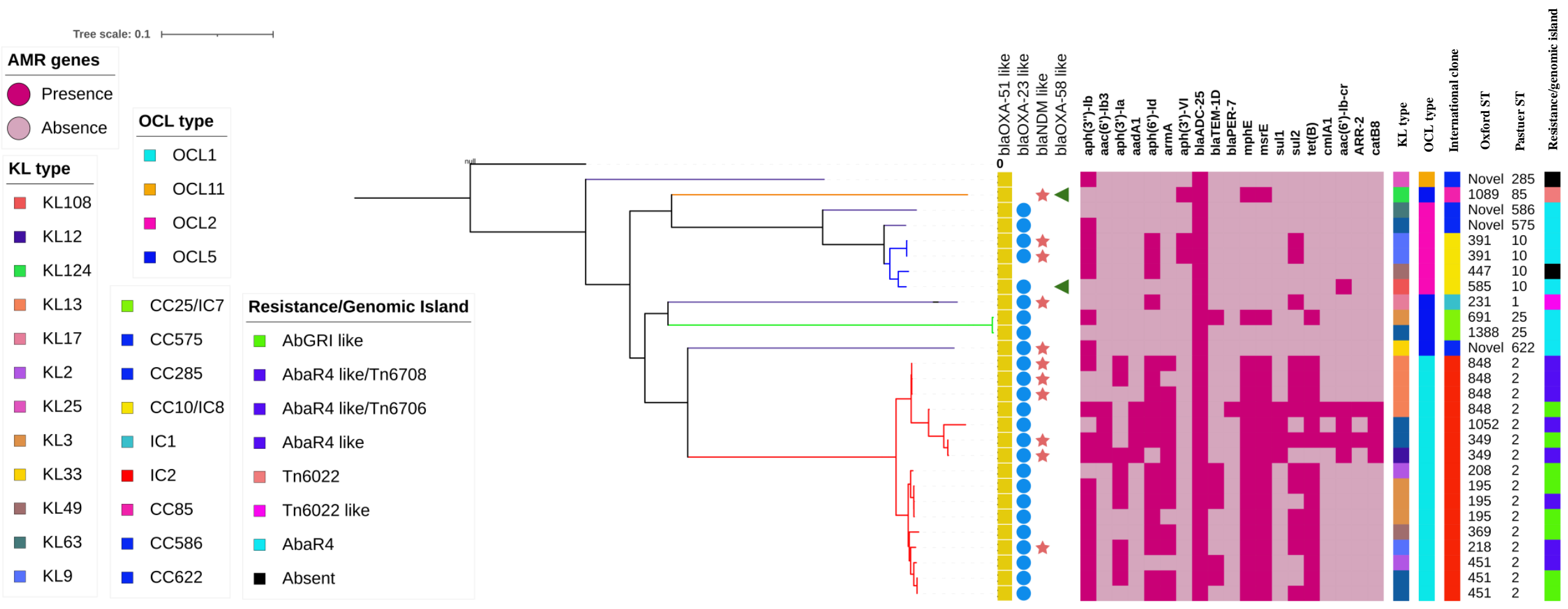

Figure 5: Single nucleotide polymorphism (SNP)-based phylogenetic tree of carbapenem resistant $A$. baumannii sequenced in this study. The colour filled shape denoted presence while the empty shape denoted absence of the respective traits. Heat map represents the presence or absence of AMR genes; Dark red indicates presence while light red indicates absence of respective gene. The capsular types (KL), outer core lipopolysaccharide types (OCL), International clones/clonal complexes and resistance/genomic islands of the CRAB isolates were represented by colour coded boxes as given in the legend. The Oxford and Pasteur scheme sequence types (STs) were given as text labels. 


\section{Discussion:}

A. baumannii has become an important hospital acquired pathogen and is of major concern due to the rapid emergence of MDR, XDR and PDR strains (Agoba et al 2018; Havenga et al 2019). Of the 17 CRAB isolates, 16 were MDR or XDR or PDR whereas one isolate was pan-susceptible. More than $85 \%$ carbapenem resistance rates in A. baumannii were reported from previous studies in India and typically associated with isolates carrying either $b l a_{\mathrm{OXA}-23}$ alone or due to both $b l a_{\mathrm{OXA}-23}$ and $b l a_{\mathrm{NDM}-1}$ which concurs with the current study (Vijayakumar et al 2016, Vijayakumar et al 2019, Vijayakumar et al 2020). We found that majority of the study isolates (13/17) encoded more than one copy of bla $a_{\text {OXA-23 }}$ gene. However, we were unable to find any high level carbapenem resistance genes in these isolates. Earlier, Hua and colleagues reported the presence of multiple copies of $b l a_{\mathrm{OXA}-23}$ among $\mathrm{CRAB}$ as a common phenomenon without increase in carbapenem resistance (Hua et al., 2016).

The current study showed the endemicity of IC2 along with the emergence of sporadic clones such as IC7 and IC8. The global epidemiology of CRAB showed the dominance of the pandemic lineage, IC2 in Asia, North America and Europe whilst IC5 and IC7 in South or Latin America (Levy-Blitchtein et al., 2018, Opazo-Capurro et al., 2019). Similarly, a recent study by Kumar and colleague (2019) described the prevalence of IC2, IC1, IC7 and IC8 among CRAB isolates from Indian hospitals (Kumar et al., 2019). Though the previous studies from India reported the predominance of IC2; the presence of isolates that belongs to IC7 and IC8 indicates the dissemination of CRAB and reinforces the fact that the international clones of CRAB isolates are wide-spread among the hospital settings in India.

Several studies reported that bla $_{\text {OXA-23 }}$ gene has relocated to chromosomes and plasmids with the help of transposons (Hamidian et al., 2019). Four different transposons harboring $b l a_{\text {OXA-23 }}$ have been described, of which $\mathrm{Tn} 2006$ is the most commonly reported 
(Chen et al., 2017). Fourteen CRAB isolates were identified with Tn2006-linked bla $a_{\text {OXA-23 }}$ in this study. Though experimental observations are not performed, carbapenem resistance in these isolates could be due to the ISAbal-mediated overexpression of bla $a_{\mathrm{OXA}-23}$ gene located in Tn2006. Occasionally, carbapenem resistance in A. baumannii could happen due to the over-expression of bla $a_{O X A-51}$ variants by insertion of ISAbal (Wong et al 2019). Earlier, Lopes and colleagues showed the insertional inactivation of bla $a_{\mathrm{OXA}-51}$ by ISAbal6 (Lopes et al 2012). In this study, presence of ISAbal6 was observed in one genome; however insertional inactivation of bla $a_{\mathrm{OXA}-51}$ like was not seen.

In A. baumannii, bla $a_{\mathrm{NDM}-1}$ gene can be encoded chromosome or by plasmid (Bonnin et al 2013). However, the current study observed A. baumannii isolates harboring $b l a_{\mathrm{NDM}-1}$ only in the chromosomes. Earlier, Jones and colleague analyzed the genetic context of $b l a_{\mathrm{NDM}-1}$ harboring A. baumannii isolates from India and reported the presence of IS26-bounded $b l a_{\mathrm{NDM}-1}$ on non-conjugative plasmid which could potentiate its mobility (Jones et al 2014). However, such finding was not observed in the current study. Unlike Enterobacteriaceae in which $b l a_{\mathrm{NDM}-1}$ often observed with single copy of truncated ISAba125 on plasmids, the dissemination of bla $a_{\mathrm{NDM}-1}$ in $A$. baumannii is always associated with a complete $\operatorname{Tn} 125$ (Poirel et al, 2012, Dortet et al, 2014). In contrast to the above statement, one genome in this study was identified with Tn 125 like linked $b l a_{\mathrm{NDM}-1}$, thereby suggesting that it could have acquired $b l a_{\mathrm{NDM}-1}$ from other species.

Presence of repAci6 harboring bla $a_{\mathrm{OXA}-23}$ and belonging to IC1 was identified in the p1AB28 plasmid. Comparative analysis revealed that AB28 carries a plasmid closely related to the reference, as it harbors bla $a_{\text {OXA-23 }}$ gene in a different context (Hamidian et al., 2014). Therefore, p1AB28 plasmid is conjugative and can spread carbapenem resistance by disseminating $b l a_{\text {OXA-23 }}$ gene into diverse clones. However, further studies are warranted to confirm the same. Another genome, AB20 belongs to IC2 and carries repAci6 conjugative 
plasmid. This plasmid harbors aphA6 gene on TnaphA6 transposon which encodes an aminoglycoside (3') phosphotransferase and confers resistance to amikacin. Previous studies from European and Asian countries reported isolates of A. baumannii with large conjugative plasmid such as, repAci6 carrying both the bla $a_{\text {OXA-23 }}$ and aphA6 genes and contribute to the dissemination of resistance to carbapenems and amikacin respectively (Towner et al., 2011; Nigro and Hall, 2016). Hamidian and colleagues compared the backbone of four closely related repAci6 plasmids and reported the carriage of Tn2006 and TnaphA6 either on the same or on the different plasmids (Hamidian et al 2015).

Genomic analysis of AbaRs in this study unveiled novel genetic configurations specific to backbones which involves either insertion of MGEs or structural modifications driven by known MGEs. For example, insertion of ISAba42 within Tn6022 backbone leads to truncated form of tniE transposition gene thereby forming Tn6022 derived element. Furthermore, surprisingly, in this study we identified an isolate (AB28) that belongs to IC1 but lacks AbaR3 type Island. Instead, it carries IC2 specific Tn6022-derived backbone which clearly indicates the possibility of independent acquisition. Tn6022-derived elements, AbaR4 and AbGRI-type elements are typically confined to IC2 (Dexi et al 2020). In this study, we also found that none of the IC2 isolates carried AbaR4 type Island; instead it was present among isolates belonging to other ICs such as IC7 and IC8. All the study isolates belonging to IC2 possess either AbaR4-like or AbGRI-like Islands with complex chimeric structures. Though the genetic events behind this process are unclear, such complex structural variation in the AbaR backbones might have resulted either due to the target sequences favorable for MGE insertion or due to the exposure of AbaRs with different MGEs in different clones. These findings indicate that AbaRs with diverse backbones might have evolved separately.

Overall, to the best of our knowledge, the present study is the first that provides a comprehensive profiling of resistance Islands (RI) together with the MGEs, acquired 
antimicrobial resistance genes and the distribution of clonal lineages among carbapenem resistant A. baumannii from India. Though the study provides a clear picture of Indian scenario, further comparative analysis with large collection of global isolates is required to understand the structural diversity and evolution of these MGEs that drives the genome plasticity of A. baumannii. 
Table 1: Genomic and epidemiological features of different clones of carbapenem resistant $A$. baumannii - Indian versus global scenario:

\begin{tabular}{|c|c|c|c|c|c|c|c|c|}
\hline \multirow{2}{*}{$\begin{array}{c}\text { International } \\
\text { clone (IC) }\end{array}$} & \multicolumn{2}{|c|}{ IC1 } & \multicolumn{2}{|c|}{ IC2 } & \multicolumn{2}{|c|}{ IC7 } & \multicolumn{2}{|c|}{ IC8 } \\
\hline & Indian & Global & Indian & Global & Indian & Global & Indian & Global \\
\hline $\begin{array}{l}\text { Antimicrobial } \\
\text { resistance } \\
\text { (AMR) genes }\end{array}$ & $\begin{array}{c}\text { bla }_{\text {OXA-23, }} \\
\text { bla }_{\mathrm{NDM}-1}\end{array}$ & $\begin{array}{l}\text { bla }_{\text {OXA-23, }} \\
\text { bla }_{\text {OXA-58 }}\end{array}$ & $\begin{array}{l}\text { bla }_{\mathrm{OXA}-23} \\
\text { bla }_{\mathrm{OXA}-58} \\
\text { bla }_{\mathrm{NDM}-1}\end{array}$ & $\begin{array}{c}\text { bla }_{\text {OXA-23, }} \\
\text { bla }_{\text {OXA-24, }} \\
\text { bla }_{\text {OXA-58, }} \\
\text { bla }_{\text {NDM-1 }}\end{array}$ & $b l a_{\text {OXA-23 }}$ & $\begin{array}{c}\text { bla }_{\text {OXA-23, }} \\
\text { bla }_{\text {NDM-1 }}\end{array}$ & $b l a_{\text {OXA-23 }}$ & $\begin{array}{c}\text { bla }_{\mathrm{OXA}-23}, \\
\text { bla }_{\mathrm{OXA}-58}, \\
\text { bla }_{\mathrm{NDM}-1}\end{array}$ \\
\hline $\begin{array}{l}\text { Insertion } \\
\text { sequence }\end{array}$ & ISAba1 & & & & & & & \\
\hline Transposon & $\begin{array}{c}\text { Tn6022, } \\
\text { Tn2006, } \\
\operatorname{Tn} 125\end{array}$ & $\begin{array}{l}\text { Tn6018, } \\
\text { Tn6019, } \\
\text { Tn6022, } \\
\text { Tn6172 } \\
\operatorname{Tn} 2006\end{array}$ & $\begin{array}{c}\text { Tn6022, } \\
\text { Tn6172, } \\
\text { Tn2006, } \\
\text { Tn6706, } \\
\text { Tn6708, } \\
\text { Tn125 }\end{array}$ & $\begin{array}{c}\text { Tn6022, } \\
\text { Tn6172, } \\
\text { Tn2006, } \\
\text { Tn2007, } \\
\text { Tn2008, } \\
\text { Tn125 }\end{array}$ & $\begin{array}{l}\text { Tn6022, } \\
\operatorname{Tn} 2006\end{array}$ & $\begin{array}{c}\text { Tn6022, } \\
\text { Tn6172, } \\
\text { Tn6183 }\end{array}$ & $\begin{array}{l}\text { Tn6022, } \\
\operatorname{Tn} 2006\end{array}$ & $\begin{array}{l}\text { Tn6022, } \\
\operatorname{Tn} 6172\end{array}$ \\
\hline $\begin{array}{l}\text { Resistance } \\
\text { Island }\end{array}$ & AbaR4 & $\begin{array}{c}\text { AbaR1, } \\
\text { AbaR3, } \\
\text { AbaR4, } \\
\text { AbaR5 } \\
\text { AbaR6, } \\
\text { AbaR7, } \\
\text { AbaR8, } \\
\text { AbaR21, } \\
\text { AbaR23, } \\
\text { AbaR24 }\end{array}$ & $\begin{array}{c}\text { AbaR4, } \\
\text { Novel AbGRIs }\end{array}$ & $\begin{array}{c}\text { AbaR4, } \\
\text { AbaR25, } \\
\text { AbaR26, } \\
\text { AbaR27, } \\
\text { AbGRI1, } \\
\text { AbGRI2, } \\
\text { AbGRI3 }\end{array}$ & AbaR4 & AbGRI2 & AbaR4 & NA \\
\hline
\end{tabular}




\begin{tabular}{|c|c|c|c|c|c|c|c|c|}
\hline $\begin{array}{l}\text { Predominant } \\
\text { STs (Oxford) }\end{array}$ & ST231 & $\begin{array}{l}\text { ST109, } \\
\text { ST207, } \\
\text { ST231, } \\
\text { ST405, } \\
\text { ST441, } \\
\text { ST491, } \\
\text { ST781, } \\
\text { ST945, } \\
\text { ST947 }\end{array}$ & $\begin{array}{c}\text { ST848, ST208, } \\
\text { ST195, ST451, } \\
\text { ST218, ST369, } \\
\text { ST349, } \\
\text { ST1052 }\end{array}$ & $\begin{array}{l}\text { ST92, } \\
\text { ST848, } \\
\text { ST208, } \\
\text { ST195, } \\
\text { ST451, } \\
\text { ST218, } \\
\text { ST369 }\end{array}$ & $\begin{array}{l}\text { ST229, } \\
\text { ST691, } \\
\text { ST993 }\end{array}$ & $\begin{array}{l}\text { ST229, } \\
\text { ST691 }\end{array}$ & $\begin{array}{l}\text { ST447, } \\
\text { ST391, } \\
\text { ST1390 }\end{array}$ & ST447 \\
\hline $\begin{array}{l}\text { Predominant } \\
\text { STs (Pasteur) }\end{array}$ & ST1 & ST1 & ST2 & ST1 & ST25 & ST25 & ST10 & ST10 \\
\hline $\begin{array}{l}\text { Level of } \\
\text { spread }\end{array}$ & Low & Medium & High & High & Low & $\begin{array}{c}\text { Low and } \\
\text { region } \\
\text { specific }\end{array}$ & Low & $\begin{array}{c}\text { Low anc } \\
\text { region } \\
\text { specific }\end{array}$ \\
\hline
\end{tabular}


Table 2. Presence of AMR genes, Mobile Genetic Elements and Resistance Islands among the 17 complete genomes of A. baumannii

\begin{tabular}{|c|c|c|c|c|c|c|c|c|c|}
\hline $\begin{array}{l}\text { Isolate ID } \\
\text { (Accession } \\
\text { number) }\end{array}$ & $\begin{array}{l}\text { Specimen } \\
\text { ID }\end{array}$ & Susceptibility & AMR gene profile & $\begin{array}{l}\text { ISAba1- } \\
\text { bla } 0 \text { OXA-51 } \\
\text { like }\end{array}$ & $\begin{array}{l}\text { ISAba1-bla } a_{0 \times A} \\
23 \text { like } \\
\text { transposon }\end{array}$ & $\begin{array}{c}\text { ISAba3-bla }{ }_{\text {OXA- }} \\
{ }_{58} \text { like }\end{array}$ & $\begin{array}{l}\text { ISAba125- } \\
\text { bla }_{\mathrm{NDM}-1} \text { like } \\
\text { transposon }\end{array}$ & Integron & $\begin{array}{l}\text { Resistance } \\
\text { Island (RI) }\end{array}$ \\
\hline $\begin{array}{c}\mathrm{AB} 01 \\
(\mathrm{CP} 040080)\end{array}$ & $\begin{array}{l}\text { SP304 } \\
\text { (Novel) }\end{array}$ & $\begin{array}{c}\text { Pan- } \\
\text { susceptible }\end{array}$ & $b l a_{\mathrm{ADC}-25}, b l a_{\text {OXA-337 }}$ & - & - & - & - & - & Absent \\
\hline $\begin{array}{c}\mathrm{AB} 02 \\
(\mathrm{CP} 035672)\end{array}$ & $\begin{array}{l}\text { VB23193 } \\
\text { (IC2) }\end{array}$ & PDR & 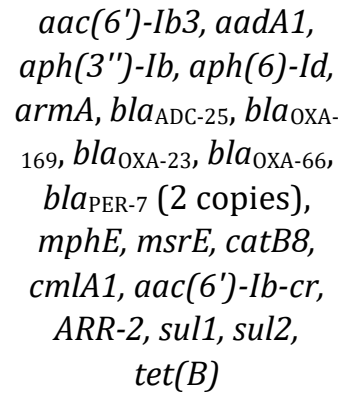 & - & $\begin{array}{l}\text { Present - } \\
\text { Tn2006 }\end{array}$ & - & - & - & $\begin{array}{l}\text { AbGRI-like } \\
\text { (Carries } \\
\triangle I S C R 2- \\
\triangle T \text { Tn10- } \\
\text { MARR like } \\
\text { region) }\end{array}$ \\
\hline $\begin{array}{c}\text { АB03 } \\
(\mathrm{CP} 050388)\end{array}$ & $\begin{array}{l}\text { VB473 } \\
\text { (IC2) }\end{array}$ & PDR & $\begin{array}{l}\text { aph(3")-Ib, aph(3')-Ia, } \\
\text { aph(6)-Id, armA, } \\
\text { bla }_{\mathrm{ADC}-25}, \text { bla }{ }_{\mathrm{NDM}-1,} \\
\text { bla }_{\mathrm{OXA}-23}(2 \text { copies), } \\
\text { bla } a_{\mathrm{XXA}-66}, m p h(E), \\
\text { msrE, sul2, tet(B) }\end{array}$ & - & $\begin{array}{l}\text { Present - } \\
\text { Tn2006 }\end{array}$ & - & Present - Tn125 & - & $\begin{array}{l}\text { AbaR4-like } \\
\text { (Carries } \\
\text { additional } \\
\text { mobL gene) }\end{array}$ \\
\hline $\begin{array}{c}\text { AB06 } \\
(\text { CP040050) }\end{array}$ & $\begin{array}{l}\text { VB16141 } \\
\text { (Novel) }\end{array}$ & PDR & $\begin{array}{c}\text { bla }_{\mathrm{ADC}-25}, \text { bla }_{\mathrm{NDM}-1} \\
\text { bla }_{\mathrm{OXA}-203}, \text { bla }_{\text {OXA-23 }}(2 \\
\text { copies })\end{array}$ & - & $\begin{array}{l}\text { Present - } \\
\text { Tn2006 }\end{array}$ & - & $\begin{array}{l}\text { Incomplete } \\
\text { Tn125 }\end{array}$ & - & AbaR4 \\
\hline $\begin{array}{c}\mathrm{AB} 10 \\
(\mathrm{CP} 040053)\end{array}$ & $\begin{array}{l}\text { VB35179 } \\
\text { (Novel) }\end{array}$ & XDR & $\begin{array}{l}\text { bla }_{\mathrm{ADC}-25}, b l a_{\mathrm{OXA}-23}(2 \\
\text { copies), } \text { bla }_{\text {OХA }-68}\end{array}$ & - & $\begin{array}{l}\text { Present - } \\
\text { Tn2006 }\end{array}$ & - & - & - & AbaR4 \\
\hline
\end{tabular}




\begin{tabular}{|c|c|c|c|c|c|c|c|c|c|}
\hline $\begin{array}{c}\text { AB11 } \\
\text { (CP040056) }\end{array}$ & $\begin{array}{l}\text { VB35435 } \\
\text { (Novel) }\end{array}$ & XDR & $\begin{array}{l}b l a_{\mathrm{ADC}-25}, b l a_{\text {OXA-144, }} \\
b l a_{\text {OXA-23 }}(2 \text { copies })\end{array}$ & - & $\begin{array}{l}\text { Present - } \\
\text { Tn2006 }\end{array}$ & - & - & - & AbaR4 \\
\hline $\begin{array}{c}\text { AB13 } \\
(\mathrm{CP} 040087)\end{array}$ & $\begin{array}{l}\text { VB35575 } \\
\quad \text { (IC2) }\end{array}$ & XDR & 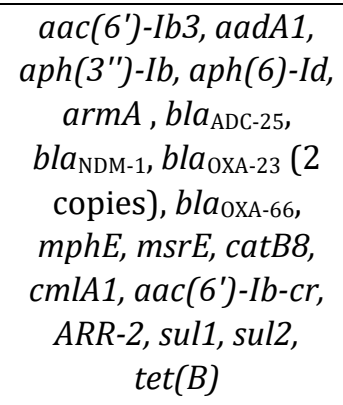 & - & $\begin{array}{l}\text { Present - } \\
\text { Tn2006 }\end{array}$ & - & $\begin{array}{c}\text { Present - Tn125 } \\
\text { like) }\end{array}$ & - & $\begin{array}{l}\text { AbGRI-like } \\
\text { (Carries } \\
\triangle \text { ISCR2- } \\
\triangle \text { Tn10- } \\
\text { MARR like } \\
\text { region) }\end{array}$ \\
\hline $\begin{array}{c}\text { AB14 } \\
\text { (CP040259) }\end{array}$ & $\begin{array}{l}\text { P7774 } \\
\text { (IC7) }\end{array}$ & XDR & $\begin{array}{c}\text { bla }_{\mathrm{ADC}-25}, \text { bla }_{\mathrm{OX \textrm {A } - 2 3}}(2 \\
\text { copies }), \text { bla }_{\text {OХА }-64}\end{array}$ & - & $\begin{array}{l}\text { Present - } \\
\text { Tn2006 }\end{array}$ & - & - & - & AbaR4 \\
\hline $\begin{array}{c}\mathrm{AB} 15 \\
(\mathrm{CP} 050385)\end{array}$ & $\begin{array}{l}\text { VB82 } \\
\text { (IC7) }\end{array}$ & XDR & $\begin{array}{l}\text { bla }_{\mathrm{ADC}-25}, \text { bla }_{\text {OХA-23, }} \\
\text { bla }_{\text {OXA-64 }}, \text { bla }_{\mathrm{TEM}-1 \mathrm{D}} \\
m p h E, m s r E, \text { tet(B) }\end{array}$ & - & $\begin{array}{l}\text { Present - } \\
\text { Tn2006 }\end{array}$ & - & - & - & AbaR4 \\
\hline $\begin{array}{c}\text { AB16 } \\
(\mathrm{CP} 050523)\end{array}$ & $\begin{array}{l}\text { VB7036 } \\
\text { (IC2) }\end{array}$ & XDR & 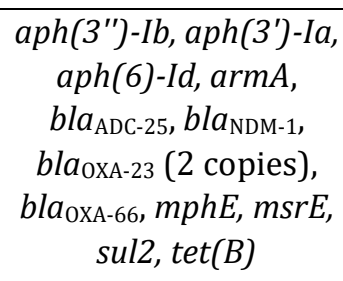 & - & $\begin{array}{l}\text { Present - } \\
\text { Tn2006 }\end{array}$ & - & $\begin{array}{c}\text { Present - Tn125 } \\
\text { like }\end{array}$ & - & $\begin{array}{l}\text { AbaR4-like } \\
\text { (Carries } \\
\text { additional } \\
\text { mobL gene }\end{array}$ \\
\hline $\begin{array}{c}\text { AB18 } \\
(\text { CP050390) }\end{array}$ & $\begin{array}{l}\text { VB723 } \\
\text { (IC2) }\end{array}$ & XDR & $\begin{array}{c}\operatorname{aph}\left(3^{\prime \prime}\right)-I b, \operatorname{arm} A, \\
\operatorname{aph}\left(3^{\prime}\right)-I a, \operatorname{aph}\left(6^{\prime}\right)-I d, \\
\text { bla }_{\mathrm{ADC}-25}, \text { bla }_{\mathrm{OXA}-23}(2 \\
\text { copies }), \text { bla }_{\mathrm{OXA}-66} \\
\text { bla }_{\mathrm{TEM}-1 \mathrm{D}}, \operatorname{mphE}, \operatorname{msr} \text {, } \\
\text { sul2, } \operatorname{tet}(B)\end{array}$ & - & $\begin{array}{l}\text { Present - } \\
\text { Tn2006 }\end{array}$ & - & - & - & $\begin{array}{c}\text { AbGRI-like } \\
\text { (Carries } \\
\text { additional } \\
\text { copy of } \\
\text { ISAba1 \& two } \\
\text { copies of } \\
\text { Tn2006) }\end{array}$ \\
\hline
\end{tabular}




\begin{tabular}{|c|c|c|c|c|c|c|c|c|c|}
\hline $\begin{array}{c}\text { AB19 } \\
(\mathrm{CP} 050410)\end{array}$ & $\begin{array}{l}\text { PM2235 } \\
\text { (IC2) }\end{array}$ & XDR & 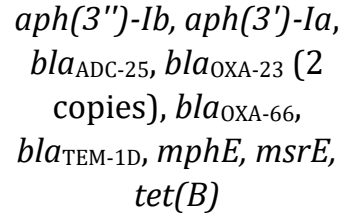 & - & $\begin{array}{l}\text { Present - } \\
\text { Tn2006 }\end{array}$ & - & - & - & $\begin{array}{l}\text { AbaR4-like } \\
\text { (Carries } \\
\text { additional } \\
\text { mobL gene }\end{array}$ \\
\hline $\begin{array}{c}\text { AB20 } \\
(\mathrm{CP} 050412)\end{array}$ & $\begin{array}{l}\text { PM2696 } \\
\text { (IC2) }\end{array}$ & XDR & $\begin{array}{c}a p h\left(3^{\prime \prime}\right)-I b, \operatorname{aph}\left(6^{\prime}\right)-I d, \\
\text { bla }_{\mathrm{ADC}-25}, \text { bla }_{\mathrm{OXA}-23}(2 \\
\text { copies }), \text { bla } \\
\text { mphE, } m s r E, \text { sul2, } \\
\operatorname{tet}(B)\end{array}$ & - & $\begin{array}{l}\text { Present - } \\
\text { Tn2006 }\end{array}$ & - & - & - & $\begin{array}{l}\text { AbGRI-like } \\
\text { (Carries } \\
\text { additional } \\
\text { copy of } \\
\text { ISAba1 \& two } \\
\text { copies of } \\
\text { Tn2006) }\end{array}$ \\
\hline $\begin{array}{c}\text { AB23 } \\
(\mathrm{CP} 050432)\end{array}$ & $\begin{array}{l}\text { PM4229 } \\
\text { (IC8) }\end{array}$ & MDR & $\begin{array}{l}\operatorname{aph}\left(3^{\prime \prime}\right)-I b, \operatorname{aph}(6)-I d, \\
\text { bla }_{\mathrm{ADC}-25}, \text { bla }_{\text {OXA-68 }}, \text { sul2 }\end{array}$ & - & - & - & - & - & - \\
\hline $\begin{array}{c}\text { AB26 } \\
\text { (CP050401) }\end{array}$ & $\begin{array}{l}\text { VB2181 } \\
\text { (IC2) }\end{array}$ & XDR & 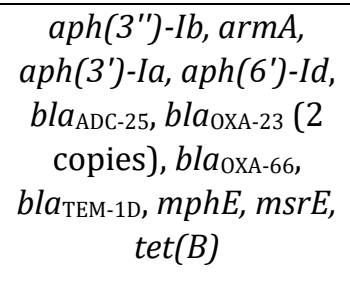 & - & $\begin{array}{l}\text { Present - } \\
\text { Tn2006 }\end{array}$ & - & - & - & $\begin{array}{l}\text { AbaR4-like } \\
\text { (Carries } \\
\text { additional } \\
\text { mobL gene }\end{array}$ \\
\hline $\begin{array}{c}\text { AB27 } \\
(\mathrm{CP} 050421)\end{array}$ & $\begin{array}{l}\text { VB2200 } \\
\text { (IC2) }\end{array}$ & XDR & 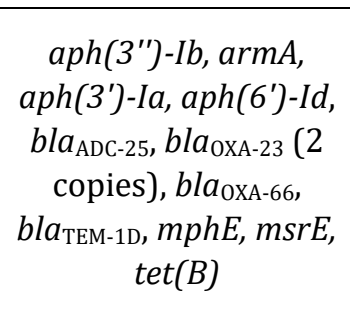 & - & $\begin{array}{l}\text { Present - } \\
\text { Tn2006 }\end{array}$ & - & - & - & $\begin{array}{l}\text { AbGRI-like } \\
\text { (Carries } \\
\text { additional } \\
\text { copy of } \\
\text { ISAba1 \& two } \\
\text { copies of } \\
\text { Tn2006) }\end{array}$ \\
\hline $\begin{array}{c}\text { AB28 } \\
(\mathrm{CP} 050403)\end{array}$ & $\begin{array}{l}\text { VB2486 } \\
\text { (IC1) }\end{array}$ & $\mathrm{XDR}$ & $\begin{array}{c}\operatorname{aph}\left(3^{\prime \prime}\right)-I b, \operatorname{aph}\left(6^{\prime}\right)-I d \\
\text { bla }_{\mathrm{ADC}-25}, \text { bla }_{\mathrm{OXA}-371} \\
\text { bla }_{\mathrm{NDM}-1}, \text { sul2 }\end{array}$ & $\begin{array}{c}\text { ISAba16 } \\
\text { present but } \\
\text { no } \\
\text { insertional }\end{array}$ & - & - & Present - Tn125 & - & $\begin{array}{l}\text { Tn6022 } \\
\text { derived } \\
\text { elements } \\
\text { (tniE- }\end{array}$ \\
\hline
\end{tabular}




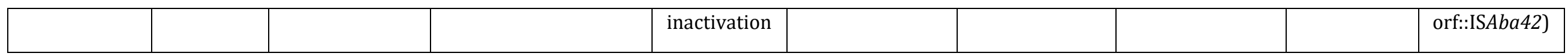

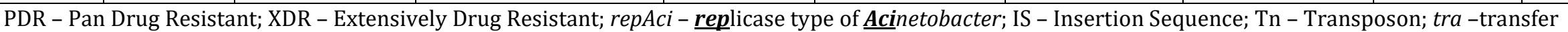
genes; Mob - mobility genes

Table 3 Characteristic features of plasmids among the 17 complete genomes of $A$. baumannii

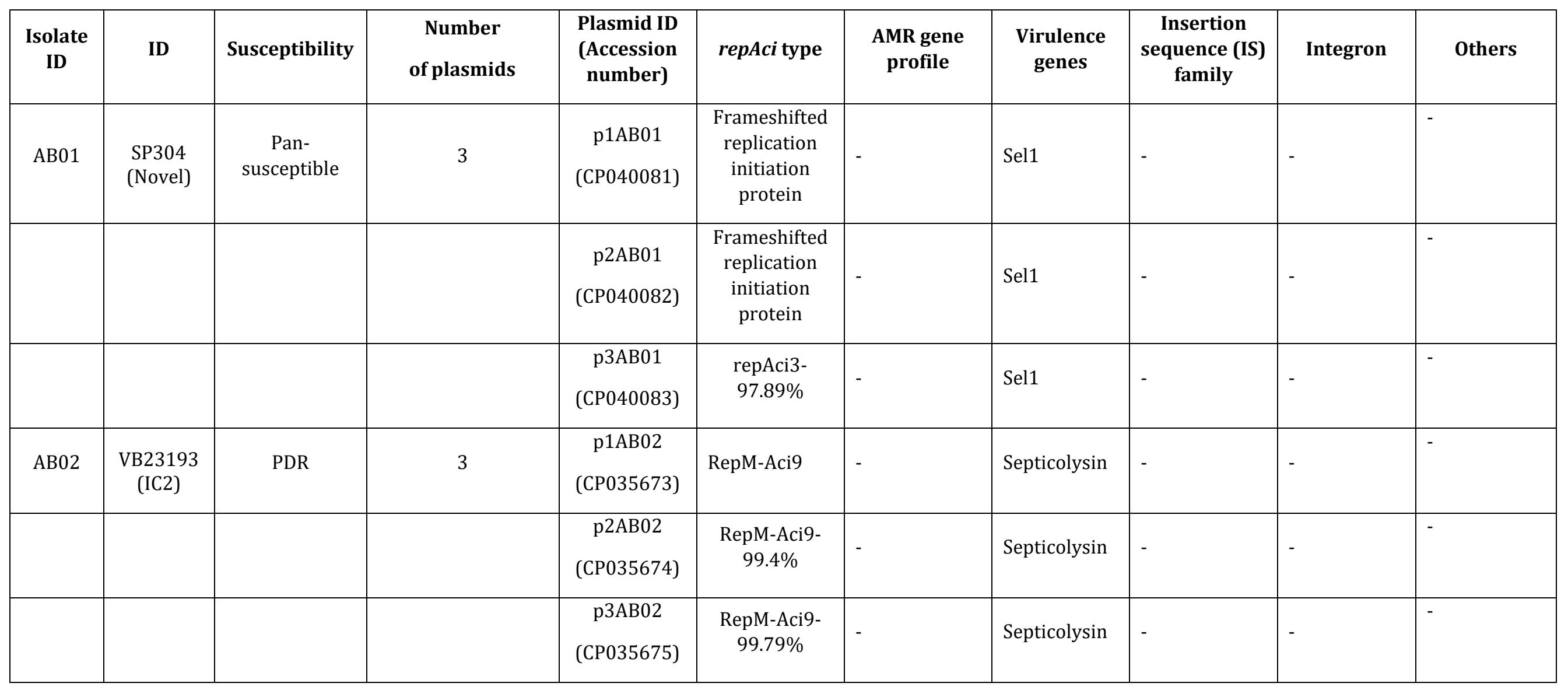




\begin{tabular}{|c|c|c|c|c|c|c|c|c|c|c|}
\hline & & & & $\begin{array}{c}\text { p6AB04 } \\
\text { (CP040046) }\end{array}$ & - & - & Septicolysin & IS3 & - & - \\
\hline AB03 & $\begin{array}{l}\text { VB473 } \\
\text { (IC2) }\end{array}$ & PDR & 1 & $\begin{array}{c}\mathrm{p} 1 \mathrm{AB} 03 \\
\text { (CP050389) }\end{array}$ & repAci4 & - & Septicolysin & IS3 & - & - \\
\hline \multirow[t]{2}{*}{ AB06 } & $\begin{array}{l}\text { VB16141 } \\
\text { (Novel) }\end{array}$ & PDR & 2 & $\begin{array}{c}\mathrm{p} 1 \mathrm{AB} 06 \\
\text { (CР040051) }\end{array}$ & Aci7-89.75\% & $\begin{array}{l}\text { aph(3")-Ib, } \\
\text { aph(6)-Id, } \\
\text { armA, blaPER- } \\
\text { 7, mph€, } \\
\text { msr€, cmlA1, } \\
\text { ARR-2, sul1, } \\
\text { sul2 }\end{array}$ & - & $\begin{array}{l}\text { IS4, IS91, IS6- } \\
\text { like,IS5-like, } \\
\text { Tn3-like }\end{array}$ & $\begin{array}{l}\text { Class 1(Int } \\
\text { I1) }\end{array}$ & - \\
\hline & & & & $\begin{array}{c}\mathrm{p} 2 \mathrm{AB} 06 \\
(\mathrm{CP} 040052)\end{array}$ & - & $\operatorname{aph}\left(3^{\prime}\right)-\mathrm{VI}$ & & & & - \\
\hline \multirow[t]{2}{*}{ AB10 } & $\begin{array}{c}\text { VB35179 } \\
\text { (Novel) }\end{array}$ & XDR & 2 & $\begin{array}{c}\mathrm{p} 1 \mathrm{AB} 10 \\
(\mathrm{CP} 040054)\end{array}$ & - & $\begin{array}{l}\text { aph(3")-Ib, } \\
\text { aph(6)-Id, } \\
\text { armA, blaPER- } \\
\text { 7, mph€, } \\
\text { msr€, cmlA1, } \\
\text { ARR-2, sul1, } \\
\text { sul2, tet(B) }\end{array}$ & - & $\begin{array}{l}\text { IS5, IS6-like, } \\
\text { Tn3-like, IS3, } \\
\text { IS91-like, IS4- } \\
\text { like }\end{array}$ & $\begin{array}{l}\text { Class 1(Int } \\
\text { I1) }\end{array}$ & - \\
\hline & & & & $\begin{array}{c}\text { p2AB10 } \\
\text { (CP040055) }\end{array}$ & Aci 4 & - & Septicolysin & IS3 & - & - \\
\hline AB11 & $\begin{array}{c}\text { VB35435 } \\
\text { (Novel) }\end{array}$ & XDR & 1 & $\begin{array}{c}\mathrm{p} 1 \mathrm{AB} 11 \\
\text { (CP040057) }\end{array}$ & - & $\begin{array}{l}\text { aph(3')-Via, } \\
\text { blaCARB-2, } \\
\text { blaPER-7, sul1 }\end{array}$ & & IS6, IS91,IS30 & - & - \\
\hline AB13 & $\begin{array}{l}\text { VB35575 } \\
\text { (IC2) }\end{array}$ & XDR & 1 & p1AB13 & repMAci9 & - & Septicolysin & - & - & - \\
\hline
\end{tabular}




\begin{tabular}{|c|c|c|c|c|c|c|c|c|c|c|}
\hline & & & & (CP040088) & & & & & & \\
\hline \multirow[t]{3}{*}{ AB14 } & $\begin{array}{c}\text { P7774 } \\
\text { (IC7) }\end{array}$ & XDR & 3 & $\begin{array}{c}\text { p1AB14 } \\
\text { (CP040260) }\end{array}$ & - & $\begin{array}{l}\text { aac(6')-Ian, } \\
\text { aph(3")-Ib, } \\
\text { aph(6)-Id, } \\
\text { armA, blaPER- } \\
\text { 7, mph€, } \\
\text { msr€, cmlA1, } \\
\text { ARR-2, sul1, } \\
\text { sul2, tet(B) }\end{array}$ & - & $\begin{array}{l}\text { IS5,IS4,IS70- } \\
\text { like,IS91,IS6,I } \\
\text { S30 }\end{array}$ & $\begin{array}{l}\text { Class 1(Int } \\
\text { I1) }\end{array}$ & - \\
\hline & & & & $\begin{array}{c}\mathrm{p} 2 \mathrm{AB} 14 \\
(\mathrm{CP} 040261)\end{array}$ & AlS_3472 & - & Septicolysin & IS3 & - & - \\
\hline & & & & $\begin{array}{c}\text { p3AB14 } \\
\text { (CР040262) }\end{array}$ & - & - & - & - & - & - \\
\hline \multirow[t]{2}{*}{ AB15 } & $\begin{array}{l}\text { VB82 } \\
\text { (IC7) }\end{array}$ & XDR & 2 & $\begin{array}{c}\mathrm{p} 1 \mathrm{AB} 15 \\
\text { (СР050386) }\end{array}$ & $\begin{array}{l}\text { RepB family } \\
\text { plasmid } \\
\text { replication } \\
\text { initiator } \\
\text { protein } \\
\text { (incomplete; } \\
\text { partial on } \\
\text { complete } \\
\text { genome) }\end{array}$ & $\begin{array}{l}\text { aac(6')-Ian, } \\
\text { aph(3")-Ib, } \\
\text { aph(6)-Id, } \\
\text { armA, } \\
\text { blaOXA-23, } \\
\text { blaPER-7, } \\
\text { mph€, msr€, } \\
\text { cmlA1, ARR-2, } \\
\text { sul1, sul2, } \\
\text { tet(B) }\end{array}$ & $\begin{array}{l}\text { MobL like, } \\
\text { septicolysin }\end{array}$ & $\begin{array}{l}\text { IS5,IS6,IS91,IS } \\
\text { 3,IS4,IS701- } \\
\text { like }\end{array}$ & $\begin{array}{l}\text { Class 1(Int } \\
\text { I1) }\end{array}$ & - \\
\hline & & & & $\begin{array}{c}\mathrm{p} 2 \mathrm{AB} 15 \\
\text { (CP050387) }\end{array}$ & AlS_3472 & - & - & - & - & - \\
\hline AB16 & $\begin{array}{c}\text { VB7036 } \\
\text { (IC2) }\end{array}$ & XDR & 2 & $\begin{array}{c}\mathrm{p} 1 \mathrm{AB} 16 \\
\text { (CP050524) }\end{array}$ & RepA_AB & - & $\begin{array}{l}\text { Sel1, } \\
\text { Septicolysin }\end{array}$ & & & - \\
\hline
\end{tabular}




\begin{tabular}{|c|c|c|c|c|c|c|c|c|c|c|}
\hline & & & & $\begin{array}{c}\text { p2AB16 } \\
\text { (CP050525) }\end{array}$ & - & - & - & & & - \\
\hline AB18 & $\begin{array}{l}\text { VB723 } \\
\text { (IC2) }\end{array}$ & XDR & 1 & $\begin{array}{c}\text { P1AB18 } \\
\text { (CP050391) }\end{array}$ & AB57_3921 & - & $\begin{array}{l}\text { Sel1, } \\
\text { Septicolysin }\end{array}$ & & & - \\
\hline AB19 & $\begin{array}{l}\text { PM2235 } \\
\text { (IC2) }\end{array}$ & XDR & 1 & $\begin{array}{c}\text { P1AB19 } \\
\text { (CP050411) }\end{array}$ & - & - & $\begin{array}{l}\text { Sel1, } \\
\text { Septicolysin }\end{array}$ & & & - \\
\hline \multirow[t]{2}{*}{ AB20 } & $\begin{array}{l}\text { PM2696 } \\
\text { (IC2) }\end{array}$ & XDR & 2 & $\begin{array}{c}\text { p1AB20 } \\
(\mathrm{CP} 050413)\end{array}$ & repAci6 & $\operatorname{aph}\left(3^{\prime}\right)-$ Via & - & IS30 like & & $\begin{array}{l}\text { T4SS, type } 4 \\
\text { TraL, TraE, } \\
\text { TraK, TraB, } \\
\text { TraV, TraC, } \\
\text { TraW, TraU, } \\
\text { TrbC, TraN, } \\
\text { TraF, TraH, } \\
\text { TraG }\end{array}$ \\
\hline & & & & $\begin{array}{c}\mathrm{p} 2 \mathrm{AB} 20 \\
(\mathrm{CP} 050414)\end{array}$ & AB57_3921 & - & $\begin{array}{l}\text { Sel1, } \\
\text { Septicolysin }\end{array}$ & - & & - \\
\hline \multirow[t]{3}{*}{ AB23 } & $\begin{array}{l}\text { PM4229 } \\
\text { (IC8) }\end{array}$ & MDR & 3 & $\begin{array}{c}\text { p1AB23 } \\
(\mathrm{CP} 050433)\end{array}$ & - & $\begin{array}{l}\text { aph(3")-Ib, } \\
\text { aph(6)-Id, } \\
\text { armA, blaPER- } \\
\text { 7, mph€, } \\
\text { msr€, cmlA1, } \\
\text { ARR-2, sul1, } \\
\text { sul2, tet(B) }\end{array}$ & MobL-like & $\begin{array}{l}\text { IS4-like, IS5, } \\
\text { IS91, IS26 }\end{array}$ & $\begin{array}{l}\text { Class } 1 \text { (Int } \\
\text { I1) }\end{array}$ & $\begin{array}{l}\text { Mercury } \\
\text { operon, T6S } \\
\text { protein, } \\
\text { Conjugal } \\
\text { transfer } \\
\text { protein, TrbI, } \\
\text { T4SS }\end{array}$ \\
\hline & & & & $\begin{array}{c}\text { p2AB23 } \\
(\mathrm{CP} 050434)\end{array}$ & Aci2-99.89\% & - & $\begin{array}{l}\text { MobA, MobL, } \\
\text { Sel1, } \\
\text { Septicolysin }\end{array}$ & - & - & - \\
\hline & & & & p3AB23 & repAci3 & - & Sel1 & - & - & - \\
\hline
\end{tabular}




\begin{tabular}{|c|c|c|c|c|c|c|c|c|}
\hline & & & & (СР050435) & & & & \\
\hline AB26 & $\begin{array}{c}\text { VB2181 } \\
\text { (IC2) }\end{array}$ & XDR & 1 & $\begin{array}{c}\text { P1AB26 } \\
\text { (CP050402) }\end{array}$ & AB57_3921 & - & $\begin{array}{l}\text { Sel1, } \\
\text { Septicolysin }\end{array}$ & - \\
\hline \multirow[t]{2}{*}{ AB27 } & $\begin{array}{l}\text { VB2200 } \\
\text { (IC2) }\end{array}$ & XDR & 2 & $\begin{array}{c}\mathrm{p} 1 \mathrm{AB} 27 \\
\text { (CP050422) }\end{array}$ & repAci1 & - & $\begin{array}{l}\text { Sel1, } \\
\text { Septicolysin }\end{array}$ & - \\
\hline & & & & $\begin{array}{c}\mathrm{p} 2 \mathrm{AB} 27 \\
(\mathrm{CP} 050423)\end{array}$ & - & $\operatorname{aph}\left(3^{\prime}\right)-V I$ & MobA, mobL & - \\
\hline \multirow[t]{4}{*}{ AB28 } & $\begin{array}{l}\text { VB2486 } \\
\text { (IC1) }\end{array}$ & XDR & 6 & $\begin{array}{c}\text { p1AB28 } \\
\text { (CP050404) }\end{array}$ & $\begin{array}{c}\text { plasmid } \\
\text { replicase } \\
\text { (repAci6) } \\
\\
\text { (PriCT_1" } \\
=" \text { Primase C } \\
\text { terminal 1 } \\
\text { (PriCT-1) }\end{array}$ & bla0XA-23 & $\begin{array}{l}\text { IS21, IS256, } \\
\text { IS66, IS4, } \\
\text { IS30 like }\end{array}$ & $\begin{array}{l}\text { T4SS, type } 4 \\
\text { TraL, TraE, } \\
\text { TraK, TraB, } \\
\text { TraV, TraC, } \\
\text { TraW, TraU, } \\
\text { TrbC, TraN, } \\
\text { TraF, TraH, } \\
\text { TraG } \\
\text { (Presence of } \\
\text { repAci6 } \\
\text { carrying } \\
\text { AbaR4 with } \\
\text { Tn2006- } \\
\text { OXA-23) }\end{array}$ \\
\hline & & & & $\begin{array}{c}\mathrm{p} 2 \mathrm{AB} 28 \\
(\mathrm{CP} 050405)\end{array}$ & repAci4 & - & - & - \\
\hline & & & & $\begin{array}{c}\text { p3AB28 } \\
\text { (CP050406) }\end{array}$ & - & $\mathrm{mph} €, \mathrm{msr} €$ & - & - \\
\hline & & & & p4AB28 & - & $\operatorname{aph}\left(3^{\prime}\right)-\mathrm{VI}$ & - & - \\
\hline
\end{tabular}




\begin{tabular}{|l|l|l|l|c|l|l|l|l|l|l|}
\hline & & & $(\mathrm{CP050407)}$ & & & & & \\
\hline & & & & $\begin{array}{c}\mathrm{p} 5 \mathrm{AB} 28 \\
(\mathrm{CP} 050408)\end{array}$ & - & - & - & & \\
\hline & & & & $\begin{array}{c}\mathrm{p} 6 \mathrm{AB} 28 \\
(\mathrm{CP} 050409)\end{array}$ & - & - & - & & & - \\
\hline
\end{tabular}




\section{References:}

1. Elhosseiny NM, Attia AS. Acinetobacter: an emerging pathogen with a versatile secretome. Emerging microbes \& infections. 2018 Dec 1;7(1):1-5.

2. Dexter C, Murray GL, Paulsen IT, Peleg AY. Community-acquired Acinetobacter baumannii: clinical characteristics, epidemiology and pathogenesis. Expert review of anti-infective therapy. 2015 May 4;13(5):567-73.

3. Lee CR, Lee JH, Park M, Park KS, Bae IK, Kim YB, Cha CJ, Jeong BC, Lee SH. Biology of Acinetobacter baumannii: pathogenesis, antibiotic resistance mechanisms, and prospective treatment options. Frontiers in cellular and infection microbiology. 2017 Mar 13;7:55.

4. O'Donnell JN, Putra V, Lodise TP. Treatment of patients with serious infections due to carbapenem-resistant Acinetobacter baumannii: How viable are the current options?. Pharmacotherapy: The Journal of Human Pharmacology and Drug Therapy. 2021 Sep;41(9):762-80.

5. Gales, A.C., Seifert, H., Gur, D., Castanheira, M., Jones, R.N. and Sader, H.S., 2019, March. Antimicrobial susceptibility of Acinetobacter calcoaceticus-Acinetobacter baumannii complex and Stenotrophomonas maltophilia clinical isolates: results from the SENTRY antimicrobial surveillance program (1997-2016). In Open forum infectious diseases (Vol. 6, No. Supplement_1, pp. S34-S46). US: Oxford University Press.

6. Indian Priority Pathogen List - Department of Biotechnology. https://dbtindia.gov.in

7. Roca Subirà I, Espinal P, Vila-Farrés X, Vila Estapé J. The Acinetobacter baumannii oxymoron: commensal hospital dweller turned pan-drug-resistant menace. Frontiers in microbiology. 2012 Apr 23;3:148.

8. Vijayakumar S, Gopi R, Gunasekaran P, Bharathy M, Walia K, Anandan S, Veeraraghavan B. Molecular characterization of invasive carbapenem-resistant Acinetobacter baumannii from a tertiary care hospital in South India. Infectious diseases and therapy. 2016 Sep 1;5(3):379-87.

9. Pagano M, Martins AF, Barth AL. Mobile genetic elements related to carbapenem resistance in Acinetobacter baumannii. brazilian journal of microbiology. 2016 Dec;47(4):785-92.

10. Partridge SR, Kwong SM, Firth N, Jensen SO. Mobile genetic elements associated with antimicrobial resistance. Clinical microbiology reviews. 2018 Oct 1;31(4):e00088-17.

11. Vijayakumar S, Anandan S, Prabaa D, Kanthan K, Vijayabaskar S, Kapil A, Ray P, Sistla S, Bhattacharya S, Wattal C, Deotale V. Insertion sequences and sequence types profile of clinical isolates of carbapenem-resistant A. baumannii collected across India over four year period. Journal of Infection and Public Health. 2019 Dec 23.

12. Salto IP, Tejerizo GT, Wibberg D, Pühler A, Schlüter A, Pistorio M. Comparative genomic analysis of Acinetobacter spp. plasmids originating from clinical settings and environmental habitats. Scientific reports. 2018 May 17;8(1):1-2.

13. Cameranesi, M.M., Paganini, J., Limansky, A.S., Moran-Barrio, J., Salcedo, S.P., Viale, A.M. and Repizo, G.D., 2020. Acquisition of plasmids conferring carbapenem 
and aminoglycoside resistance and loss of surface-exposed macromolecule structures as strategies for the adaptation of Acinetobacter baumannii CC104O/CC15P strains to the clinical setting. Microbial genomics, 6(9).

14. Bi D, Xie R, Zheng J, Yang H, Zhu X, Ou HY, Wei Q. Large-scale identification of AbaR-type genomic islands in Acinetobacter baumannii reveals diverse insertion sites and clonal lineage-specific antimicrobial resistance gene profiles. Antimicrobial agents and chemotherapy. 2019 Apr 1;63(4):e02526-18.

15. Bi D, Zheng J, Xie R, Zhu Y, Wei R, Ou HY, Wei Q, Qin H. Comparative Analysis of AbaR-Type Genomic Islands Reveals Distinct Patterns of Genetic Features in Elements with Different Backbones. Msphere. 2020 May 27;5(3):e00349-20.

16. Kim DH, Park YK, Ko KS. Variations of AbaR4-type resistance islands in Acinetobacter baumannii isolates from South Korea. Antimicrobial agents and chemotherapy. 2012 Aug 1;56(8):4544-7.

17. Hamidian M, Hall RM. AbaR4 replaces AbaR3 in a carbapenem-resistant Acinetobacter baumannii isolate belonging to global clone 1 from an Australian hospital. Journal of antimicrobial chemotherapy. 2011 Nov 1;66(11):2484-91.

18. Mancilla-Rojano J, Castro-Jaimes S, Ochoa SA, Bobadilla del Valle M, Luna-Pineda VM, Bustos P, Laris-González A, Arellano-Galindo J, Parra-Ortega I, HernándezCastro R, Cevallos MA. Whole-genome sequences of five Acinetobacter baumannii strains from a child with leukemia M2. Frontiers in microbiology. 2019 Feb 6;10:132.

19. Hamidian M, Nigro SJ. Emergence, molecular mechanisms and global spread of carbapenem-resistant Acinetobacter baumannii. Microbial genomics. 2019 Oct;5(10).

20. Turton JF, Woodford N, Glover J, Yarde S, Kaufmann ME, Pitt TL. Identification of Acinetobacter baumannii by detection of the blaOXA-51-like carbapenemase gene intrinsic to this species. Journal of clinical microbiology. 2006 Aug 1;44(8):2974-6.

21. Weinstein MP, Patel JB, Bobenchik AM. Clinical and Laboratory Standards Institute. 2018. Performance standards for antimicrobial susceptibility testing. M.;100:148-9.

22. Weinstein MP, Patel JB, Bobenchik AM, Campeau S, Cullen SK, Gallas MF. Clinical and laboratory standards institute. Performance standards for antimicrobial susceptibility testing. 2019:88-9.

23. Vasudevan K, Ragupathi NK, Jacob JJ, Veeraraghavan B. Highly accurate-single chromosomal complete genomes using IonTorrent and MinION sequencing of clinical pathogens. Genomics. 2020 Jan 1;112(1):545-51.

24. Ershov V, Tarasov A, Lapidus A, Korobeynikov A. IonHammer: Homopolymerspace hamming clustering for IonTorrent read error correction. Journal of Computational Biology. 2019 Feb 1;26(2):124-7.

25. Wick RR, Judd LM, Gorrie CL, Holt KE. Unicycler: resolving bacterial genome assemblies from short and long sequencing reads. PLoS computational biology. 2017 Jun 8;13(6):e1005595.

26. Walker BJ, Abeel T, Shea T, Priest M, Abouelliel A, Sakthikumar S, Cuomo CA, Zeng Q, Wortman J, Young SK, Earl AM. Pilon: an integrated tool for comprehensive microbial variant detection and genome assembly improvement. PloS one.

2014;9(11). 
27. Parks DH, Imelfort M, Skennerton CT, Hugenholtz P, Tyson GW. CheckM: assessing the quality of microbial genomes recovered from isolates, single cells, and metagenomes. Genome research. 2015 Jul 1;25(7):1043-55.

28. https://www.genomicepidemiology.org/

29. https://kaptive-web.erc.monash.edu/

30. https://www-is.biotoul.fr/blast.php

31. https://cge.cbs.dtu.dk/services/MLST/

32. Seemann T. Snippy: fast bacterial variant calling from NGS reads.

33. Croucher NJ, Page AJ, Connor TR, Delaney AJ, Keane JA, Bentley SD, Parkhill J, Harris SR. Rapid phylogenetic analysis of large samples of recombinant bacterial whole genome sequences using Gubbins. Nucleic acids research. 2015 Feb 18;43(3):e15-.

34. Price MN, Dehal PS, Arkin AP. FastTree 2-approximately maximum-likelihood trees for large alignments. PloS one. 2010 Mar 10;5(3):e9490.

35. Letunic I, Bork P. Interactive Tree Of Life (iTOL) v5: an online tool for phylogenetic tree display and annotation. Nucleic acids research. 2021 Jul 2;49(W1):W293-6.

36. Agoba EE, Govinden U, Peer AK, Osei Sekyere J, Essack SY. IS Aba1 Regulated OXA-23 Carbapenem Resistance in Acinetobacter baumannii Strains in Durban, South Africa. Microbial Drug Resistance. 2018 Nov 1;24(9):1289-95.

37. Havenga B, Ndlovu T, Clements T, Reyneke B, Waso M, Khan W. Exploring the antimicrobial resistance profiles of WHO critical priority list bacterial strains. BMC microbiology. 2019 Dec 1;19(1):303.

38. Elabd FM, Al-Ayed MS, Asaad AM, Alsareii SA, Qureshi MA, Musa HA. Molecular characterization of oxacillinases among carbapenem-resistant Acinetobacter baumannii nosocomial isolates in a Saudi hospital. Journal of Infection and Public Health. 2015 May 1;8(3):242-7.

39. Vijayakumar S, Wattal C, Oberoi JK, Bhattacharya S, Vasudevan K, Anandan S, Walia K, Veeraraghavan B. Insights into the complete genomes of carbapenemresistant Acinetobacter baumannii harbouring bla OXA-23, bla OXA-420 and bla NDM-1 genes using a hybrid-assembly approach. Access microbiology. 2020;2(8).

40. Hua X, Shu J, Ruan Z, Yu Y, Feng Y. Multiplication of bla OXA-23 is common in clinical Acinetobacter baumannii, but does not enhance carbapenem resistance. Journal of Antimicrobial Chemotherapy. 2016 Dec 1;71(12):3381-5.

41. Levy-Blitchtein S, Roca I, Plasencia-Rebata S, Vicente-Taboada W, VelásquezPomar J, Muñoz L, Moreno-Morales J, Pons MJ, del Valle-Mendoza J, Vila J. Emergence and spread of carbapenem-resistant Acinetobacter baumannii international clones II and III in Lima, Peru. Emerging microbes \& infections. 2018 Dec 1;7(1):19.

42. Kumar S, Patil PP, Singhal L, Ray P, Patil PB, Gautam V. Molecular epidemiology of carbapenem-resistant Acinetobacter baumannii isolates reveals the emergence of blaOXA-23 and blaNDM-1 encoding international clones in India. Infection, Genetics and Evolution. 2019 Nov 1;75:103986.

43. Kim DH, Choi JY, Kim HW, Kim SH, Chung DR, Peck KR, Thamlikitkul V, So TM, Yasin RM, Hsueh PR, Carlos CC. Spread of carbapenem-resistant Acinetobacter 
baumannii global clone 2 in Asia and AbaR-type resistance islands. Antimicrobial agents and chemotherapy. 2013 Nov;57(11):5239-46.

44. Saranathan R, Vasanth V, Vasanth T, Shabareesh PR, Shashikala P, Devi CS, Kalaivani R, Asir J, Sudhakar P, Prashanth K. Emergence of carbapenem nonsusceptible multidrug resistant Acinetobacter baumannii strains of clonal complexes 103B and 92B harboring OXA-type carbapenemases and metallo- $\beta$-lactamases in Southern India. Microbiology and immunology. 2015 May;59(5):277-84.

45. Saranathan R, Kumari R, Kalaivani R, Suresh S, Rani A, Purty S, Prashanth K. Detection of ISAba1 in association with a novel allelic variant of the $\beta$-lactamase ADC-82 and class D $\beta$-lactamase genes mediating carbapenem resistance among the clinical isolates of MDR A. baumannii. Journal of medical microbiology. 2017 Mar 7;66(2):103-11.

46. Vijayakumar S, Mathur P, Kapil A, Das BK, Ray P, Gautam V, Sistla S, Parija SC, Walia K, Ohri VC, Anandan S. Molecular characterization \& epidemiology of carbapenem-resistant Acinetobacter baumannii collected across India. The Indian journal of medical research. 2019 Feb;149(2):240.

47. Nigro SJ, Hall RM. Structure and context of Acinetobacter transposons carrying the oxa23 carbapenemase gene. Journal of Antimicrobial Chemotherapy. 2016 May 1;71(5):1135-47.

48. Turton JF, Ward ME, Woodford N, Kaufmann ME, Pike R, Livermore DM, Pitt TL. The role of IS Aba1 in expression of OXA carbapenemase genes in Acinetobacter baumannii. FEMS microbiology letters. 2006 May 1;258(1):72-7.

49. Wong MH, Chan BK, Chan EW, Chen S. Over-expression of ISAba1-linked intrinsic and exogenously acquired OXA type carbapenem-hydrolyzing-class D-ß-lactamaseencoding genes is key mechanism underlying carbapenem resistance in Acinetobacter baumannii. Frontiers in microbiology. 2019 Dec 4;10:2809.

50. Lopes BS, Evans BA, Amyes SG. Disruption of the bla OXA-51-like gene by IS Aba16 and activation of the bla OXA-58 gene leading to carbapenem resistance in Acinetobacter baumannii Ab244. Journal of antimicrobial chemotherapy. $2012 \mathrm{Jan}$ 1;67(1):59-63.

51. Bonnin RA, Poirel L, Naas T, Pirs M, Seme K, Schrenzel J, Nordmann P. Dissemination of New Delhi metallo- $\beta$-lactamase-1-producing Acinetobacter baumannii in Europe. Clinical Microbiology and Infection. 2012 Sep 1;18(9):E362-5.

52. Jones LS, Toleman MA, Weeks JL, Howe RA, Walsh TR, Kumarasamy KK. Plasmid carriage of bla NDM-1 in clinical Acinetobacter baumannii isolates from India. Antimicrobial agents and chemotherapy. 2014 Jul;58(7):4211-3.

53. .Poirel L, Bonnin RA, Boulanger A, Schrenzel J, Kaase M, Nordmann P. Tn125related acquisition of blaNDM-like genes in Acinetobacter baumannii. Antimicrobial agents and chemotherapy. 2012 Feb 1;56(2):1087-9.

54. Dortet L, Poirel L, Nordmann P. Worldwide dissemination of the NDM-type carbapenemases in Gram-negative bacteria. BioMed research international. 2014 Oct;2014. 
55. Bertini A, Poirel L, Mugnier PD, Villa L, Nordmann P, Carattoli A. Characterization and PCR-based replicon typing of resistance plasmids in Acinetobacter baumannii. Antimicrobial agents and chemotherapy. 2010 Oct 1;54(10):4168-77.

56. Towner KJ, Evans B, Villa L, Levi K, Hamouda A, Amyes SG, Carattoli A. Distribution of intrinsic plasmid replicase genes and their association with carbapenem-hydrolyzing class D $\beta$-lactamase genes in European clinical isolates of Acinetobacter baumannii. Antimicrobial agents and chemotherapy. 2011 May 1;55(5):2154-9.

57. Hamidian M, Ambrose SJ, Hall RM. A large conjugative Acinetobacter baumannii plasmid carrying the sul2 sulphonamide and strAB streptomycin resistance genes. Plasmid. 2016 Sep 1;87:43-50 
